AL-AZHAR UNIVERSITY

BULLETIN OF THE FACULTY

OF

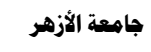

هجلة كلية اللغات والترجمة

LANGUAGES \& TRANSLATION

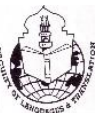

الإرهاب الإسرائيلي في أدب الطفل العبري

قصة "ניר נגד סאלים- نير ضيد سليم" لأمنون ثيرنر

أنموذجًا

د. شيماء مصطفى محممل موسىى

مدرس الأدب العربي الحديث والمعاصر

كلية الدراسـات الإنسانية

جامعة الأزهر 


\section{الإرهاب الإسرائيلي في أدب الطفل العبري \\ قصة "ניר נגד סאלים نير ضد سليم" لأمنون قيرنر أنموذجًا}

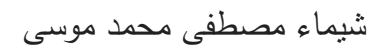

قسم اللغة العبرية وآدابها، كلية الدراسات الإنسانية، جامعة الأزهر، القاهرة، مصر . البريد الإكتروني: shaimaa.moussa@azhar.edu.eg

تتحدث القصة عن الحرب والثجاعة، والمواجهة، والثُكل، والعنف الناتج عن الصراع الإسرائيلي الفلسطيني،

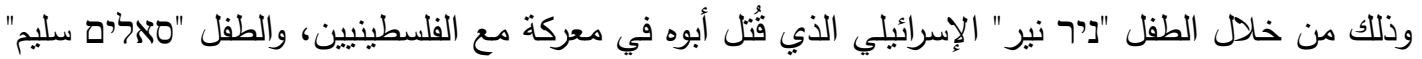
العربي الذي قُتل أخوه الصغير برصاص جنود الاحتلال الإسرائيلي، ورفضت أسرته التورط في عملية إرهابية

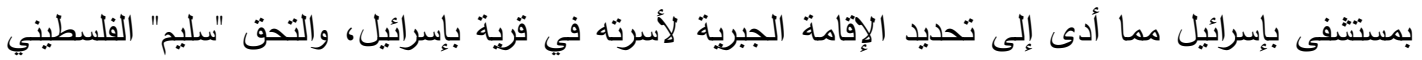
بمدرسة إسرائيلية مع "نير" الإسرائيلي، وصار وجود نير وسليم في فصل دراسي واحد يمثل شيئًا مختلفا في لئي

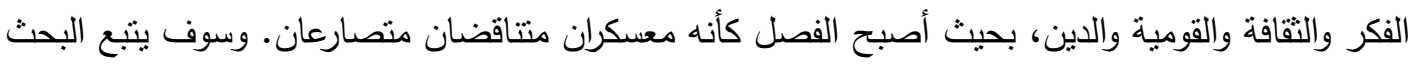

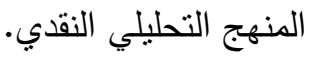
الكلمات المفتاحية: الإرهاب، إسرائيل، أمنون فيرنر ، أدب، الطفل، عبري

\section{Israeli terrorism in the Hebrew Children's Literature The Story of "Nir versus Saleem" (ניר נגד סאלים) by Amnon Werner As An Example} Shaimaa Mustafa Mohammed Moussa

Department of Hebrew Language and Literature, Faculty of Humanities, AlAzhar University, Cairo, Egypt.

Email: shaimaa.moussa@azhar.edu.eg

\section{Abstract:}

The story is about war, courage, confrontation, bereavement and violence resulting from the Israeli-Palestinian conflict. This is represented by the character of "Nir", the Israeli child whose father was killed in a battle with the Palestinians, and by the character of Saleem, the Arab-Palestinian child whose younger brother was killed by the Israeli occupation soldiers. Saleem's family refused to be involved in a terrorist operation targeting a hospital in Israel. This led to restricting their residence to a village in Israel. The Palestine child, Saleem, enrolled in Israeli school with the Israeli child "Nir". Their presence in the same classroom represented something different in thought, culture, nationality and religion, where the classroom became like two contradictory camps. This research will follow the critical analytical approach.

Keywords: Terrorism, Israel, Amnon Werner, literature, child, Hebrew 
مما لا شك فيه أن للأدب أثرا لا يستهان به على الطفل ولا سيما الأطفال الإسرائيليين، وتتشئتهم على أدب يهدف إلى زرع العنف والكراهية تجاه كل ما هو عربي، ومن المؤثرات التي تسهم في نشر ذلك في نفس الطفل الإسرائيلي المناهج التعليمية في المدراس الإسرائيلية التي تستند على مضامين صهيونية قائمة على أساس ديني وعلماني، حتى إن مفهوم السلام يتم غرسه بصورة مغايرة للواقع، وهى: أن يكون العرب تحت السيادة الإسرائيلية، إضافة إلى تتشئة الأجيال الإسرائيلية الجديدة بصورة ممزوجة بروح العسكرة والتجنيد في الجيش للتوسع والاحتلد والعنف؛ بحجة إنقاذ الأرض، وتحقيق الوعد الإلهي المزعوم.

\section{منهج البحث:}

سيتبع البحثُ المنهج التحليلي النقدي، فينقسم إلى شقين: التحليلي والنقدي؛ أما التحليلي فيعتمد على تحليل العوامل الموجودة في قصة "ניר دגד هאלים نير ضد سليم" ومعرفة المزيد عن كينونتها، وأما النقدي فمن خلاله يمكن إصدار الأحكام في ضوء ما تم تحليله في القصة.

\section{هدف البحث}

دراسة ظاهرة الإرهاب في قصة "ניר נגד هאלים نير ضد سليم": لأمنون شيزنر ، وبيان كيفية انعكاس ذلك على أدب الطفل العبري. فرضبات/تساؤلات البحث:

1- هل سيتخلب العنف كأيديولوجيا أو أن الواقع سيسيطر عليها؟ 2- هل يمكن تحقيق السلام وفقا لروئية الكاتب؟ 3- هل سيتخذ الصراع الإسرائيلي الفلسطيني اتجاها جديدا يطرحه الأدب؟ سوف تكون عناصر البحث على النحو الآتي: 1- مقدمة: العنف والإرهاب. 2- الإرهاب وعلاقته بأدب الطفل العبري. 3- ماذا يريد الكاتب الإسرائيلي من أطفال بلاده؟ 
4- أدب الطفل العبري، رؤى وتحولات. 5- أدب الطفل العبري والقبم.

6- قصة "ניר رגד סאלים نير ضد سليم": أمنون فيرنر • 7- مظاهر العنف والإرهاب في قصة "ניר נגד סאלים نير ضد سليم"

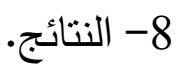
9- ثبت المصادر والمراجع. 
مقدمة: العنف والإرهاب

العنف والإرهاب وجهان لعملة واحدة، إذ إن العنف هو النواة الأساسية للعمل الإرهابي،

وهو سلوك عدواني غير سوي يرجع إلى دوافع سياسية، أو عقدية تبرز في النصوص التوراتية. أما الإرهاب فهو في اللغة: الخوف والفزع والعنف الذي يملأ الصدر ويغلفه ويشعر صاحبه بعدم الاطمئنان، ويُراد به الأفعال الجنائية الموجهة ضد دولة ما، ويكون الغرض منها إثارة الفزع والخوف لدى الجمهور، أيَّا كانت بواعثه، أو أغراضه؛ تتفيذا لعمل فردي أو جماعي يهدف لإلقاء الرعب بين الناس وترويعهم بإيذائهم، أو تعريض حياتهم وحريتهم للخطر (1). من هذا المنطلق ظهر مصطلح "العنف الإرهابي"، فالإرهاب عبارة عن عنف منظم، ومن هنا يمكن القول: إن كلَّ إرهابي عنيفُّ وليس كلٌ عنيفٍ إرهابيَّا. هذا عن العنف والإرهاب بشكل عام، أما عن أهداف الإرهاب في الفكر اليهودي فنتلخص فيما يأتي: 1- تأسيس دولة إسرائيل وعاصمتها القد، نمتا من العراق شرقا إلى مصر غربا "من النيل إلى الفرات"، وبيُعَدُّ ذلك دافعًا سياسيًّا عسكريَّا. 2- التحكم في الثعوب وتسخيرها لخدمتهم؛ إيمانا منهم بعقيدة أنهم "شعب الله المختار"، وهو دافع عَقَدِيْ (2).

\section{الإرهاب وعلاقته بأدب الطقل العبري:}

يعد أدب الطفل من المنصات المهمة التي يمكن من خلالها توجيه الطفل نحو قيمة معينة ولاسيما أدب الطفل العبري، ظهر حسب ما أجمع عليه الباحثون خلال القرن السابع عشر

(1) ـ اللو اء د/محمد فتحي عيد: الإر هاب و المخدر ات، جامعة نايف العربية للعلوم الدينية، الطبعة الأولى 2005م، ص 112، 117. (2) ناصر عبداله الغفاري، ناصر عبدالكريم العقل (د)، الموجز في الأديان و الدذاهب المعاصرة، دار الكنوز، السعودية 2005م، ص 405 40، 41. 
في فرنسا على يد الثاعر "تثارلز بيرو(3)"، وهو الأدب الموجه للطفل، فيشمل أفكارًا وأخيلةً تتفق ومستويات نمو الطفل وحاجاته المعرفية والثقافية والعاطفية والسلوكية والمهارية. من سماته: أنه أدب مزدوج يتوافر فيه البُعد الفني من جهة، والبُعد التربوي النفسي من جهة أخرى، ويهتم أيضا بالثكل، والأسلوب، والخيال، وعناصر فنية أخرى(4)، ذو حبكة بسيطة، ويعكس الأيديولوجية والقيم الخاصة بالمجتمع الذي يكتب به(5)؛ ولذا يستخدم أداةَ تأثيرٍٍ ووسيلةً سيطرةٍ على أفعال الطفل. أما إذا تحدثتا عن أدب الطقل العبري فالأمر يبدو مختلفا تماما؛ فهو أدب يدخل ضمن المنظومة الاستراتيجية لإسرائيل، وهي استراتيجية مرتبطة بالتغيرات السياسية سواء من ناحيةٍ أيديولوجية أو واقعية، وترجع بداياته إلى نهاية القرن الثامن عشر عام 1790م في برلين بظهور كتاب يحتوي على أدب الطفل المكتوب بالعبرية، وهو كتاب: "איטליاן إيتاليون" بقلم "אהרוا בן וاלית أهارون بن فيليت"، يحتوي على مقتطفات أدبية مختارة للطفل. وفي ذلك يذكر "אדיר دمן أدير كوهين" أن أدب الطفل العبري المعاصر في فلسطين ظهر منذ عام 1905م. والمعروف أن أدب الطفل العبري لم يظهر في مكان واحد؛ فقد بدأ في وسط أوروبا والولايات المتحدة، ثم واصل تطوره في شرق أوروبا، ووصل إلى ذروته في فلسطين، وربما كانت البداية الحقيقية لأدب الطفل -كما يقول "בן זאב بن زئيف"- هي بداية القرن التاسع عشر (6).

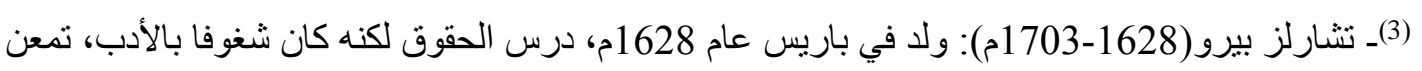

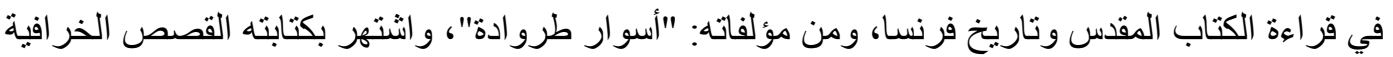

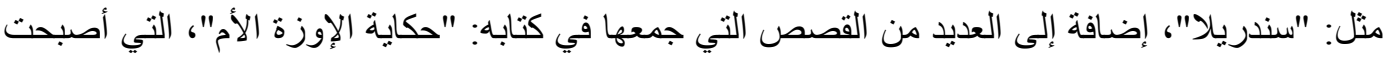

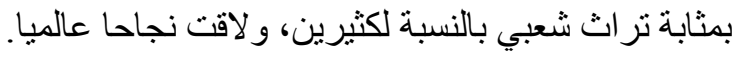
Hitchhiker's Guide to the Galaxy - Charles Perrault http://hitchhikersgui.de/Charles_Perrault - 41912019 - 11:40 pm.

(4) أحمد زلط (د): مؤثرات أيديولوجية في أدب الطفل العبري (مقارنة وتأويل)، عالم الفكر، العدد الرابع،

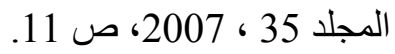

(5)- יעל עף-סקר - שלום, מלחמה, וילדות: ייצוג הסכסוך הישראלי ערבי בספרות הילדים

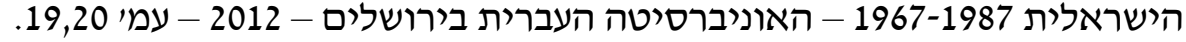
(6) سعيد عبد السلام (د): در اسة معجمية لمصطلحات الأدب، عبري-عربي، مع مسرد للألفاظ العربية، مرجع

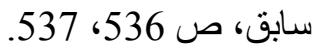


ازدهر أدب الطقل العبري بين الحربين العالميتين الأولى والثانية في جالتسيا وليتوانيا ووارسو، ويولندا. وقد تحدثت "לאה גולדברג ليئه جولدبرج(7)" عن هذا التطور قائلة: "نما أدب الطفل الإسرائيلي جنبا إلى جنب مع "الصبار "(8)، تغذى بمضمونه، واكتسب صورته اللائقة من خلال الاتصال المباشر مع الطفل الذي يعيش حياته متحدثا بعبرية تلك الفترة، كما استقى ذلك أيضا من خلال ترجمات أفضل ما كتب في أدب الطفل باللغات الأخرى". مر أدب الطفل العبري بفترة ازدهار في النصف الثاني من القرن العشرين، وكان هذا التطور في الكيف والكم على حد سواء، بداية من الأدب المكتوب بلغة ركيكة حتى تطور، وصار منل أي أدب ينمو ويزدهر ، ويُوجَّه إلى قرائه بالعبرية؛ ليُّكرهم بأن العبريةَ هي لغتُهم الأم، حيث أسهم الأدباء في الازدهار الروحاني لجيل الصباريم الأوائل الذين تربى على كتقهم جيلّ الأدباء والشعراء من مواليد فلسطين الذين نشروا نتاجهم الأدبي في أثثاء قيام الدولة، وبدأوا عهدهم الحديث في الأدب العبري، وقد ساعد على ذلك ثناثة عوامل أساسية: المدرسة الجديدة التي تُرس لطلابها اللغة العبرية الحية؛ بهدف خلق جيل جديد من القراء الأطفال الثغوفين بالقراءة. الأدب الد"قيّم" للكبار بتياراته المختلفة، حيث رأى كُتابُه كثيرًا من ردود فعل القُراء الثُبُان لمعرفة احتياجاتهم؛ للاهتمام بها في كتاباتهم.

(7)- לאה גולדברג ليئة جولدبرج (1911-1970): شاعرة، أديبة كاتبة مقالات ومترجمة، ولدات في بروسيا

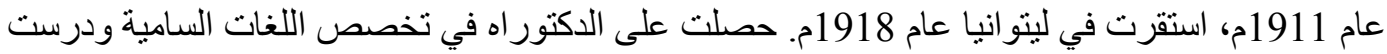

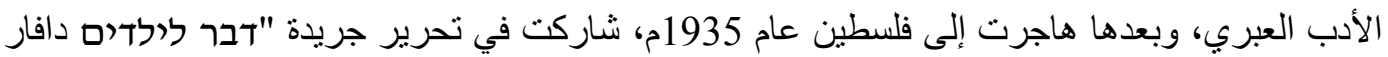

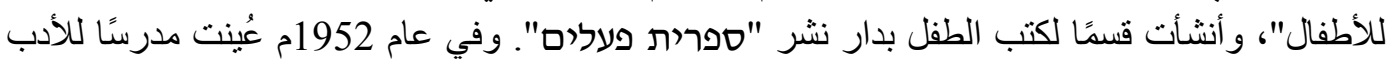

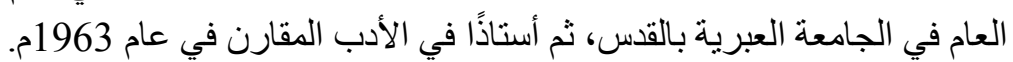

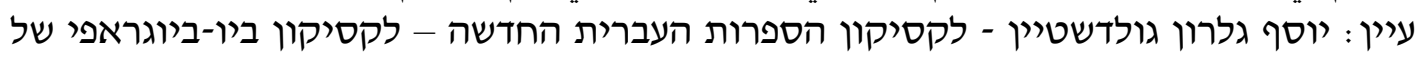

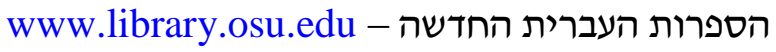

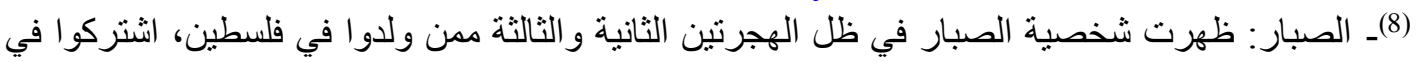

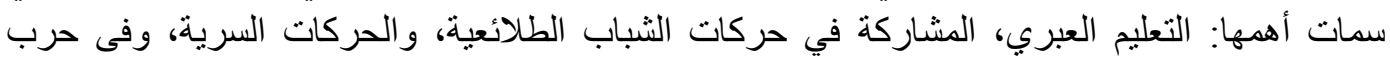

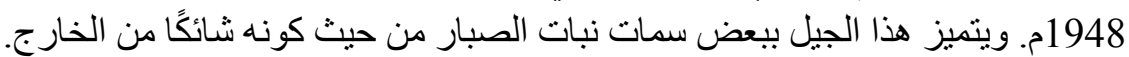

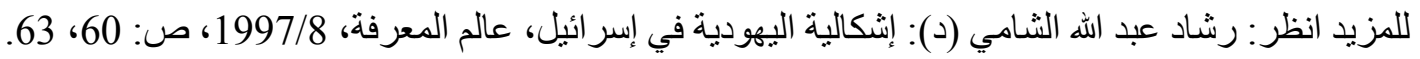


أدب الطقل العالمي، الذي ثُرجمت مئات المؤلفات منه إلى العبرية، ترك أثرًا بالغًا على

ذوق القراء سواء من حيث الموضوعات أو أسلوب الكتاب(9).

يمتل الأدباء الذين اهتموا بتقديم أعمال للطفل مجموعتين؛ منهم من كتب للكبار والصغار، ومنهم من كتب للصغار فقط على النحو الآتي:

الأولى: تضم مجموعة الأدباء الذين أنتجوا أدبًا خارج فلسطين، ومع هجرتهم إلى فلسطين حاولوا أن يوجهوا كتاباتهم نحو موضوعات جديدة تتعلق بالطفل، سواء أكانت هذه الموضوعات شعرية أم نثرية وبأسلوب جديد مختلف، ومن بين هؤلاء الأدباء "'لاקد פיכמן يعقوب فيخمان (10)"، "אביגדור המאירי أقثدور همائيري(11)" ، وآخرون. كتب هؤلاء الأدباء للكبار والصغار ، واحتلت كتاباتهم للأطفال جزءًا مهمًا وقيّمًا من إجمالي كتاباتهم. الثانية: تضم مجموعة أدباء الطفل الذين هاجروا إلى فلسطين في سن صغير، أو ولدوا بها وبدأوا بها كتاباتهم. هؤلاء الأدباء نبعت قصصهم وقصائدهم من خلا اتصالهم اليومي مع الطفل، فقد رأوا في أدب الطفل أساس قصدهم وغاياتهم، حيث استقوا تطلعاتهم من الواقع الإسرائيلي الجديد.

(9)- אוראיל אופק - ספרות ילדים העברית 1948: 1900 - כרך שני - עמ' 621.

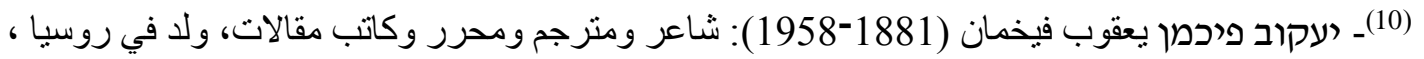

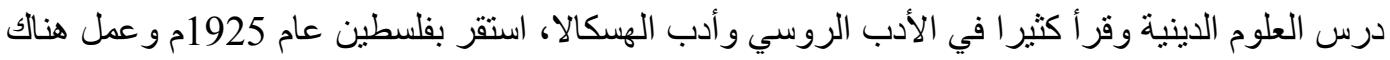

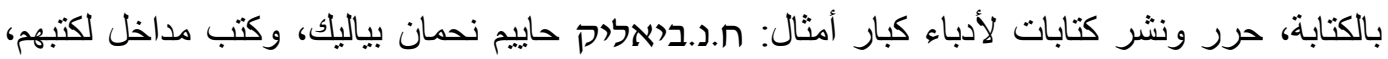

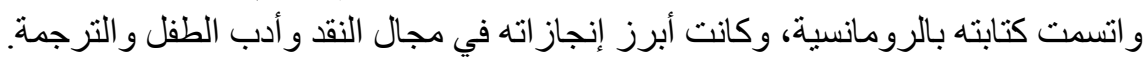

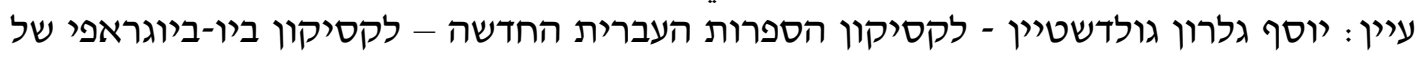

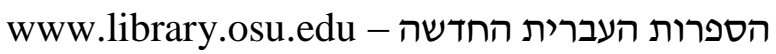
(11)- אביגדור המאירי أفيجدور همائيرى (1890-1970م): ولد بالمجر، وتلقى تعليما يهوديا دينيا، كان ناشطا صهيونيا منذ شبابه، في 1913م صسار صحفيا تابعا للكونجرس الصهيوني الحادي عشر في فينا، و هنالك

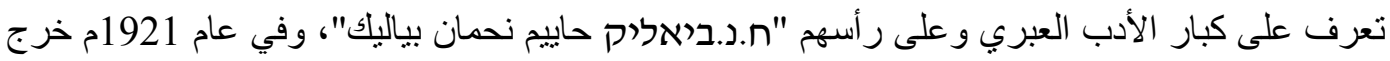

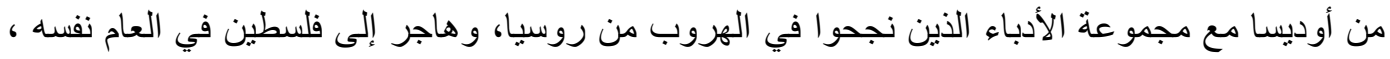

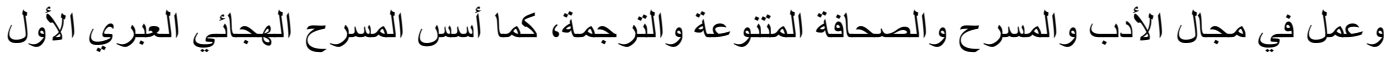

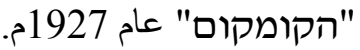
עיין: יוסף גלרון גולדשטיין - לקסיקון הספרות העברית החדשה - לקסיקון ביו-ביוגראפי של

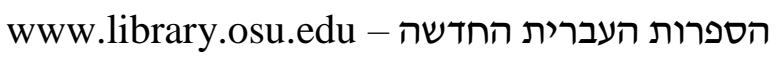


ومن الأدباء البارزين من تلك المجموعة "ناحوم جوتمان נחוه גاטמן(12)"، وآخرون. (13) يقسم أدباء الطفل ما يكتبونه وفقا للمراحل العمرية للطقل على النحو الآتي: 1) הגיל הרך וילדי גן: أطفال الروضة من 2-5 سنوات. 2) ילדים צעירים: أطفال صغار من 6-9 سنوات. 3) ילדים בוגרים: أطفال في بداية مرحلة البلوغ من 9-12 سنة. 4) נلاרים צעירים: شباب، غلام. 5) נערים בוגרים: شباب، مراهق.

ومن خلال القراءة في أدب الطفل العبري نجد أن للعنف والإرهاب نوعين هما: العنف المادي الذي يتمنل في اغتصاب أرض فلسطين والتحريض على العنف والعمليات الإرهابية، والعنف المعنوي الذي يتمنل في تزبيف الحقائق ومحاولة جعل اليهود هم الأحق بفلسطين وأرضها، وتصوير صاحب الأرض الفلسطيني في صورة المغتصب المعادي للسامية؛ حيث اتخذوا من عقائدهم الدينية - شعب اله المختار ، أرض الميعاد، الوعد الإلهي- سببًا لترسيخ مفهوم الحق في الأرض؛ لذا وظف أدباء الطفل العبري الفكر الصهيوني لخلق صورة مغايرة للواقع؛ فينشأ الطفل الإسرائيلي متمسكا بهذا المفهوم، ومن ثَم بناء أجيال تؤمن بالأيديولوجية الصهيونية وتوجهاتها العنصرية العنيفة. إن أدب الطفل العبري منذ قيام الدولة -وهو أدبٌ مُجَنَّد- ذو أهداف محددة تتمنل في خلق جيل جديد من القراء الصغار الذين يتمسكون بأرضهم ولغتهم، أي: إنه "أدبٌ صهيونيٌّ

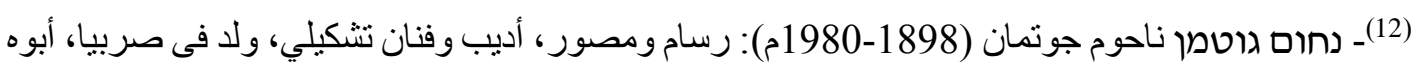

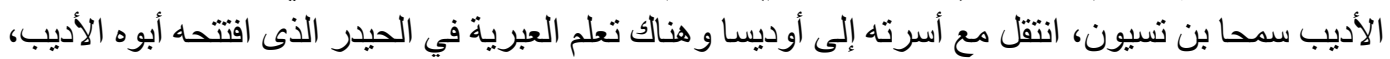

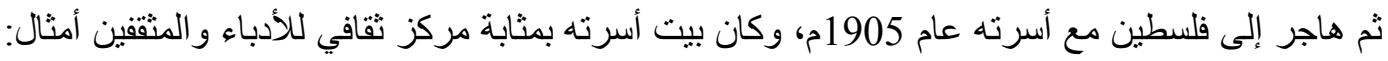

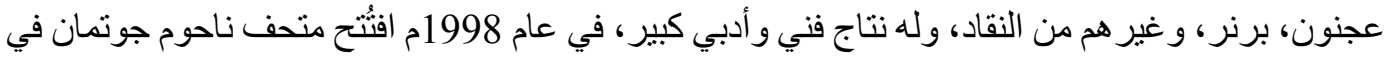

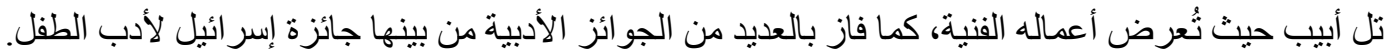

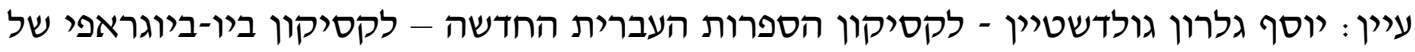

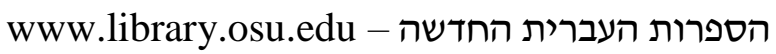
(13)- אוראיל אופק - ספרות ילדים העברית 1900: 1948 - כרך שני - עמי 622. 
خالصُ"، مُكَنَّ بالقيم القومية، وقد بدا ذلك بارزًا في أعمال بعض الكُتاب الإسرائيليين منل: "גרגור לקרן הקיימת جرجرة نحو الصندوق القومي" لـ "אנדה פינקר פלד-עמיר أندا فينكار فيلدعمير (14)"، "נשמור لاל ארצנו فلنحافظ على أرضنا" لـ "לאה גולדברג ليئه جولدبرج"(15). ماذا بريد الكاتب الإسرائيلي من أطقال بلاده؟

تقول الناقدة "تامرا مازور": "إن الظاهرة التي تهزنا بعنف هي أدب الطفل في البلاد، حيث نجد أن الأطفال تتخاطف الكتب بلهفة وشوق كبيرين، هذه الكتب التي تركز دائما على موضوع واحد، هو تصوير الأطفال اليهود على أنهم جبابرة عظماء لا يُقهرون، يهزمون العرب الأغبياء بسهولة ويسر ، هؤلاء الذين بريدون أن يقتلونا من أجل المتعة الذاتية فقط"(16). نخلص من هذا القول إلى أن أدب الطفل العبري في ظاهره يجذب الطفل رغم ما يحويه من عنف وعدوانية ضد العرب والفلسطينيين؛ لأنه يدخل ضدن المنظومة الاستراتيجية لإسرائيل، وهذا يعني أن مثل هذا الأدب لم يُكتب إلا لأهداف محددة وموجهة. إضافة إلى ذلك حَرصَ الكيانُ الصهيوني على تغذية المناهج التعليمية الدراسية في إسرائيل ووضعها في قالب فكري ثقافي اعتقادي؛ وذلك لأن التعليم هو الجانب المباشر للمفاهيم، أما الأدب فهو الجانب غير المباشر بدرجة ما، وفي ذلك يحذر "أورئيل أوفيك" أحد دارسي أدب الطفل من خطورة نشوء نمط معين من التفكير يتمنل في الموقف ضد شخصية العربي الفلسطيني

(14)- אנדה פינקרפלד-עמיר أندا فينكرفيلد-عمير (1902-1981م): ولات في بولندا عام 1902م، هاجرت

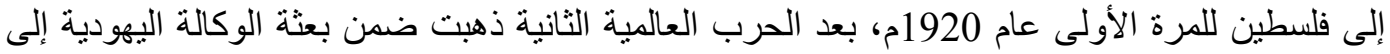

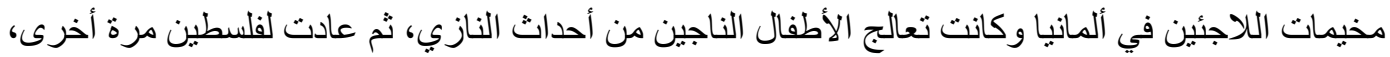

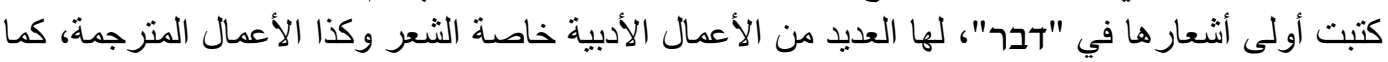

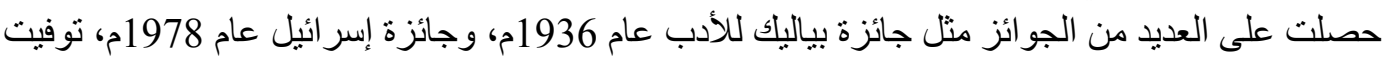

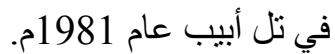
עיין: יוסף גלרון גולדשטיין - לקסיקון הספרות העברית החדשה - לקסיקון ביו-ביוגראפי של

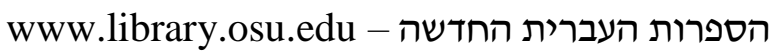
(15)

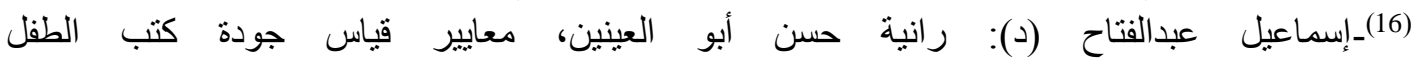
(محددات/انتقاد/اختيار/نقد/تحليل وتطوير أدب الطفل)، مرجع سابق، ص 29 29، 31، 122. 
الذي ينشأ عليه كل يهودي صهيوني منذ الصغر، ويكبر معه بتأثنر من الواقع السياسي الاجتماعي الإسرائيلي (17). ومن الجهود التي يبذلها الكيان الصهيوني لتحقيق ذلك على سبيل المثال: أن جامعة حيفا تعقد لقاءً يحضره الطفل مع الثخصيات الأدبية الثهيرة المختلفة يهدف لتوسيع مدارك الطفل وتجاربهم الحياتية الصغيرة، كما أدرجوا البحث في أدب الطفل جزءًا مهمًّا لا يتجزاً من دراسة الأدب والثقافة في إسرائيل، كما تم تخصيص مؤتمر دولي لأدب الطلل، على سبيل المثال: المؤتمر الدولي الثاني لأدب الطفل الذي أُقيم عام 1994م في نل أبيب، والذي شارك فيه العديد من الأدباء والباحثين في أدب الطفل من أنحاء العالم(18). إن منظومة التعليم في إسرائيل تعكس الحوار والواقع الإسرائيلي، وكذا عدم الاستقرار الأمني الذي يعيشه المجتمع الإسرائيلي، كما أن هذه المنظومة تُعد الطفل الإسرائيلي منذ نعومة أظافره من خلال مسارين متقابلين لكنهما متضادان؛ الأول: المنظور الجماعي المتمنل في المهمة العسكرية المستقبلية، والثاني: المنظور الفردي المتمنل في إعداد الطفل للمواطنة داخل إسرائيل، مع ضرورة استخلال أبطال الماضي القدامى في الأعمال القصصية للطفل؛ لأنها تمنل قاعدة مؤثرة على مشاعر الطفل من حيث السلوك(19). يتضح إذن أن أدب الطفل بهذا النمط التعليمي يدعم شعور الطفل ووعيه بحتمية الحرب؛ من أجل ضمان وُجودِه وبقائهِ وحب الحياة العسكربة.

(17) أورئيل أوفلك: الحذر ! سم قاتل، سلسلة قصص الفتبان "حسمبا" ليجئال موسينزون، مجلة قضايا إسر ائلية،

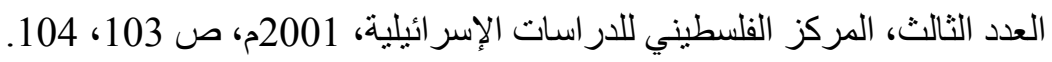

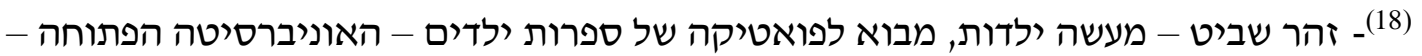

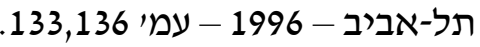
עיין גם : יעל לקסמן-בהט - ילדות טובות : הבניית יחסים מגדריים בספרות הילדים הישראלית

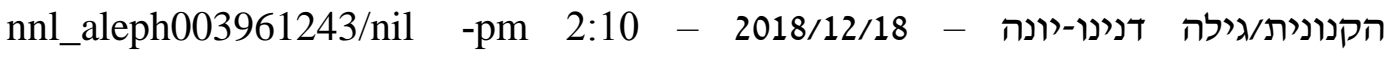
(www.beta.nli.org/ar/books/

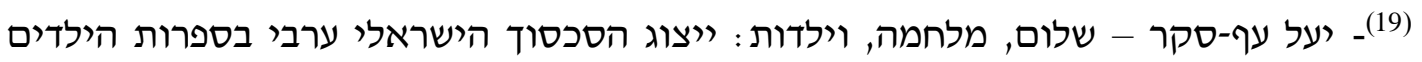
הישראלית 1967-1987 - האוניברסיטה העברית בירושלים - 2012 - עמ' 22. 


\section{أدب الطقل العبري، رؤى وتحولات:}

برز الاهتمام بأدب الطفل العبري بعد الإعلان عن قيام الدولة عام 1948م، على أساس

أن الطفلَ الإسرائيلي هو المادة الخام التي يتم استخلالها وتغذيتها ببذور العنف والإرهاب لخدمة الأهداف الصهيونية، كما أكد على ترسيخ الثقافة اليهودية الصهيونية من خلال ما عبر به قائلًا: "ماذا يمكن أن أقرأ لو كنت طفلًا أعيش في هذا الواقع؟ نحن نعيش في زمن الصراع مع العرب، نعيش فيما يمكن أن نطلق عليه: "حقول الام"؛ لذا من واجبنا أن نبتعد عن كتابة القصص الجميلة...هذا سيوقعنا في كارثة نحن في غنى عنها. ترى ماذا سيكون موقف الطفل الذي تفاجئه الحرب وهو يقرأ قصة الطائر المغرد؟....هذا تضليل لا يمكن أن نسمح به"(20. كما يذكر أيضا "ثراجا أغافنى" الباحث في الكتاب المقدس: "حين تكون إسرائيليَّا يجب عليك أن تتحمل مسئولية عظيمة، فنحن شعب الأنبياء، ويجب أن نكون منالا وأنموذجا، وعلى الطفل أن يكون منل بطل القصة تماما يتعلم منه الحب والولاء للوطن، وتسخير الإمكانات كافة من أجل أهله ووطنه وأصدقائه ومجتمعه"(21). ويتفق ذلك مع ما ورد في بروتوكولات حاخامات صهيون التي تحرض على العنف والقوة والإرهاب؛ حيث ذُكر في البروتوكول الأول: "...يجب أن يكون شعارُنا كلَّ وسائل العنف والخديعة. إن القوة المحضة هي المنتصرة في السياسة. يجب أن يكون العنف هو الأساس. إن العنف الأعمى -وحده- هو العامل الرئيس في قوة الدولة، فيجب أن نتمسك بخطة الخديعة والعنف، ويكفينا أن يُعرف أننا ذوو عنف في القضاء على كل تمرد"(22).

(20) ـ محمد الحمامصي: السيد نجم في أول در اسة لأدب الطفل العبري كثفاً للمجتمع الإسر ائيلي، موقع "إيلاف"،

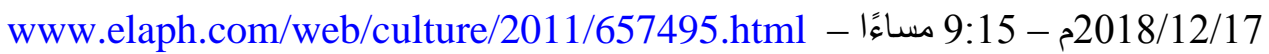
(21)- יעל לקסמן-בהט - ילדות טובות: הבניית יחסים מגדריים בספרות הילדים הישראלית

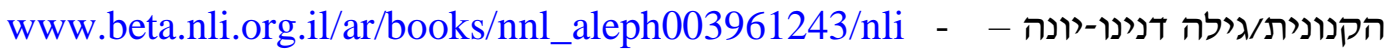
18/12/2018 - 2:10 pm.

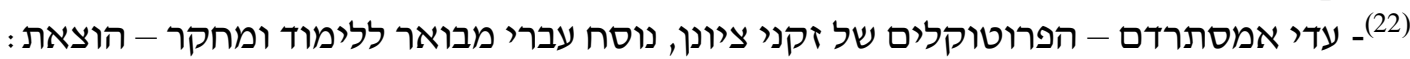

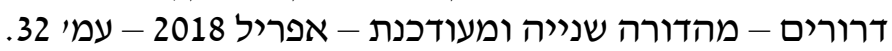


طرح بعض الأدباء تساؤلا: هل أدب الطفل الجيد هو الذي لا يتعلق بالقيم (كالعنف والإرهاب على سبيل المثال)؟ وكانت الإجابة هي: إنه لا يوجد أدب عديم القيمة، ولكن بالأحرى أن نتحدث عن القيم الظاهرة والقيم الخفية التي يصعب على الطفل التمييز بينها في النص، أو القيم الموجودة التي تكون ظاهرة لدرجة سيطرتها على العمل (23). الجدير بالذكر أنه تسيطر على الساحة الأدبية بعض القيم التي يتتاولها أدب الطفل العبري منل: الحرب، الانتقام، الدمار، الدفاع عن النفس مقابل العيش، وبعض القيم والمصطلحات الأخرى منل: السلام، التصالح، الأخوة والعيش المشترك، وقد وضع الأديب أمنون ثيرنر في قصته موضوع الدراسة هذه القيم مقابل تلك(24)، وتم تشجيع قراءة الكتب التي تعبر عن قيم التسامح والسلام والإنسانية بدلا من الأعمال التي تتجع على العنصرية والعدوانية والتمييز والانعزالية، حتى إن هناك بعض المواقع التي تختص بأدب الطفل جعلت البحث على الموقع وفق بعض الموضوعات منل: סاבלנות تسامح، התנגדות לגזענות مناهضة العنصرية، فضلا عن قائمة المواقع المرشحة التي تتتاول تلك الموضوعات(25)، بناء على ذلك يتم تحليل أدب الطفل العبري وفقا للقيم التي يحتويها منل: الاحترام الشخصي والاجتماعي، قبول الآخر، الحفاظ على البيئة، حب الشعب والبلد، حب الدين اليهودي، الحفاظ على القانون، السعادة والروحانية والسلام...إلخ (26)؛ ولكن من البدَهي ألا يكون ذلك هو التوجه السائد للدولة.

ناصر عبداله الغفاري، ناصر عبدالكريم العقل (د): الموجز في الأديان والمذاهب المعاصرة، دار الكنوز،

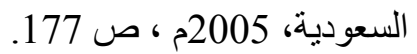

- http://culture-agent.comnir-salim/- ספרות ילדים סטרילית?- סוכן תרבות 21\12\201811:15 pm - http://on-the-left-side.org.il/ - אמנון ורנר - כמה מילים על הסכסוך בספר ילדים 22/12/2018- 8:00 pm. (25)- שונית כהן - ספרות למען סובלנות, רשימה של ספרי ילדים ונוער נגד גזענות ולעידוד

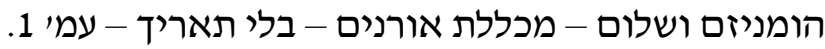

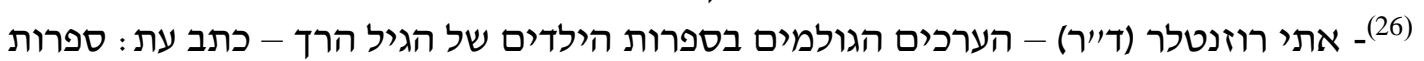

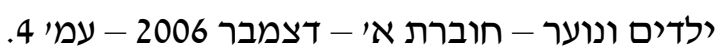


تقودنا رؤية بعض النقاد إلى طرح نساؤلٍ: هل يعكس أدب الطفل الواقع العنيف بكل

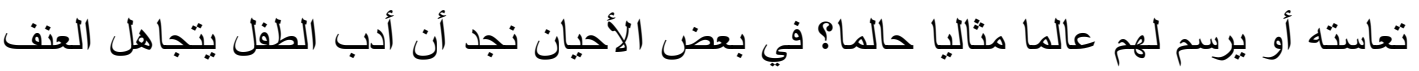

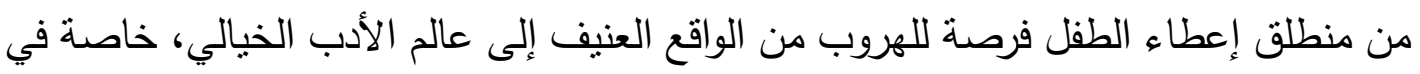

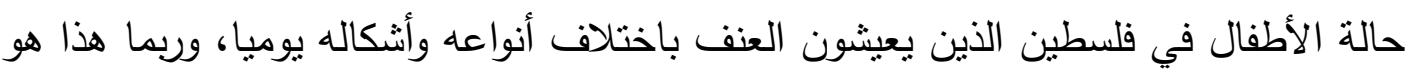
السبب وراء ندرة الكتب الواقعية التي تعكس ممارسات الاحتلال، والعنف الذي يعاني منه الطفل

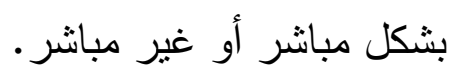
إذن، كيف يتم وصف العلاقات بين اليهود والعرب في أدب الطقل العبري؟ وما القيم والوسائل التي يعبر عنها الأديب ليدركها الطقل وعليها يبني توجهه في علاقاته ومعاملاته

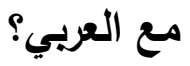
الإجابة على متل هذه الأسئلة نجدها فيما ركز عليه العديد من الأدباء الذين تنبوا هذا الفكر في بعض أعمالهم، على سبيل المثال: 1- "פנים מכוערים במראה وجوه قييحة بالمرآة" (פרופ' אדיר כהן د.أدير كوهين 1985) 2- "אנחנו והם نحن وهم" (ענבל פרלסון عنبال برلسون 2000)، 3- "ילדי האור המופלאים أطفال النور الرائعون" (ליליאן ויסברגר ليليان فيسبرجر 2003) 4- "מסע בירושלים לאי האפשר رحلة من القس إلى المستحيل" (אניטה יעקביהו أنيتا يعقوفياهو 2006) (27).

إضافة إلى ما سبق ركز أدباء آخرون في كتاباتهم للطفل على العمليات الإرهابية والآثار التي ترتبت عليها كما في: رواية "להיاת בת של ציارי لأن أكون ابنة لصهيوني" تأليف دانيلا

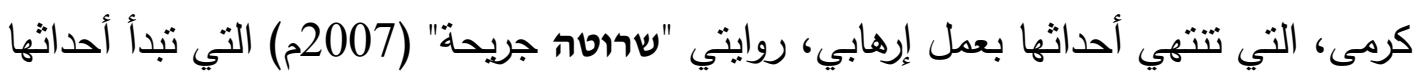
بعملية إرهابية، وقصة "هלטה לאחור سالتا إلى الوراء" لتامار فيرتر ذهفى (2008م)، وقصة ביקום (27) דו קיום: כיצד מתוארים היחסים בין יהודים וערבים בספרות הילדים - מאמר באתר: ביקורים: ספרות ילדים אמנותית עם אחריות חברתית - - 9:35 pm - 14/4/2019 www.bikurim.wordpress.com/2008/10/06/103/ 0 
"יונה חצי לבנה حمامة نصف بيضاء" لإيلنا زايدمان (2010م) (28) "ילקוט בלי אלימות، ילקוט של אהבה مقتطفات بلا عنف، مقتطفات حب" سمدار شير (2003م)(29. بناء على نماذج الأعمال المذكورة أعلاه، إذا تتبعنا بعض إحصائيات نمو أدب الطقل العبري من الثمانينيات حتى عام 2017م، سبتضح ما يأتي: من 1985م حتى عام 2015م، عبرت خربطة وضعها "אלישע רודין أليشع رودين" (30) لكتب الطفل التي تم إصدارها في الفترة من 1985م حتى 2015م، وأوضح في جزء من الإصدارات وصف شخصية العربي وكذا وصف العلاقة بين الثعبين الفلسطيني والإسرائيلي في كتب الطفل من خلال عرض المشكلات الموجودة على الساحة منل: الأفكار والمعتقدات الدينية القديمة، العمليات الإرهابية المتواصلة وقتل أفراد الثعبين لبعضهما، والصراعات المستمرة، وعند وصول تلك الأعمال بين يدي الطفل فإنها تواجه واقعًا ملييًا بالكراهية والعنف والدماء تجاه الآخر، ويشتمل ذلك على حلقات متتوعة؛ جزء منها عن شخصبة العربي، في حين أن الجزء الآخر يمثل انتقادا لسياسة إسرائيل، وبدخل هذا النمط في أدب الطفل ضمن إطار "هوרות רדיקאלית אקטיביסטית أدب راديكالي واقعي" يهدف إلى تقديم ثقافة سياسية وقراءة ناقدة،

(28)- דרי שי רודין - דמות הערבי בספרות הישראלית לילדים ולנוער : 1985-2015 - עמ' 57,56. https://www.dyellin.ac.il/sites/default/files/journals/childrens_literature/aug2015/a ugust2015_dmuthaarvi.pdf (29)- אתי רוזנטל (ד"ר)- הערבים הגלומים בספרות הילדים של הגיל הרך - כתב עת : ספרות ילדים ונוער - חוברת א' - דצמבר 2006 - עמ' 5.

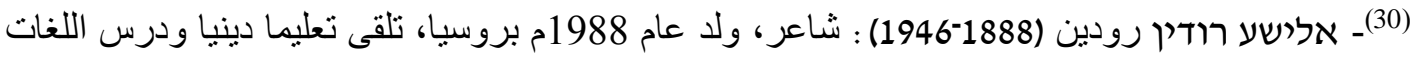

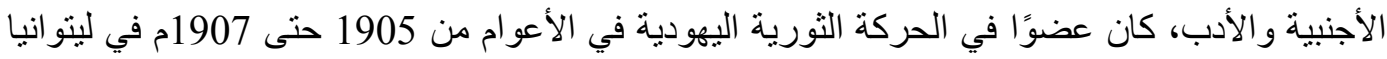

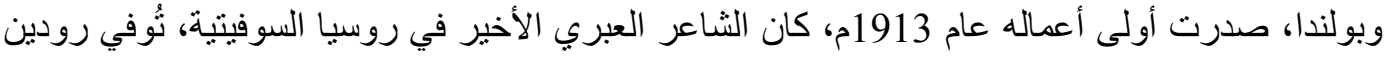

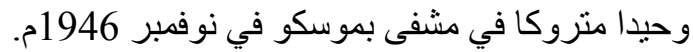
עיין: יוסף גלרון גולדשטיין - לקסיקון הספרות העברית החדשה - לקסיקון ביו-ביוגראפי של

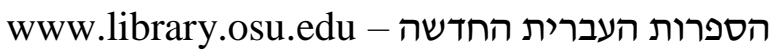


ومن أمتلة ذلك: قصة "להציל את שימבה أنقذ سيمبا" تأليف "נעמי לפיטסקי نعمى لفيتسكى"

(2008م) وتتاولت العنف من وجهات نظر متعددة تجاه البشر والحيوان والعنف الاجتماعي(31).

منذ عام 2013م حظيت بعض الموضوعات باهتمام كبير في منظومة التعليم الإسرائيلية

على رأسها قبول الآخر، فبدأت مبادرة في المنظومة التعليمية؛ لنشر بعض القيم الاجتماعية مثل: "هاבלנות تنامح" ضمن البرنامج التعليمي الذي أُطلق عليه عنوان: "האחר הוא אני الآخر هو أنا"(32)، وهو ما يحاول الأديب طرحه في القصة محل الدراسة رغم تأكيده على الإرهاب في مواضع عدة.

وفي عام 2016م قدم التقرير السنوي للمكتبة القومية "הספרייה החדשה المكتبة

الحديثة" حصرًا بعدد الأدباء والكُتّاب، حيث كان من إصدارات عام 2016م حوالي (48\%) تخص أدب الطفل (35\%) منها كَتَبها أديبات، كما ارتفع عدد الأعمال المنشورة ليصل إلى حوالي (1000) كتاب للأطفال في السنة خلا العقد الأخير • وبالبحث والاطلاع على بعض النماذج الأدبية لأدب الطفل تتضح الأيديولوجيا والبنية التربوية والنفسية وراء الثعارات والقيم المعلنة لاى الكيان الصهيوني مخالفة للواقع وتتبت الأيديولوجية الصهيونية. وفي عام 2017 مدصدرت آخر إحصائية لكتب الطفل توضح أن 86\% من الإصدارات إضافة إلى 14\% لأدب الطفل الحريدي كانت باللغة العبرية.

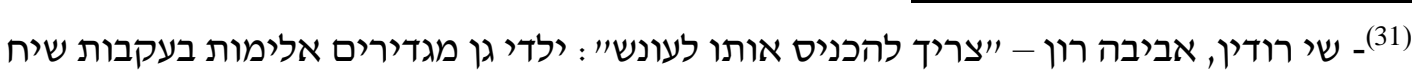

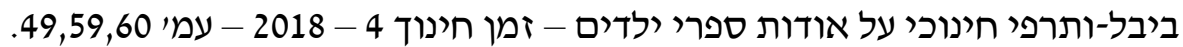

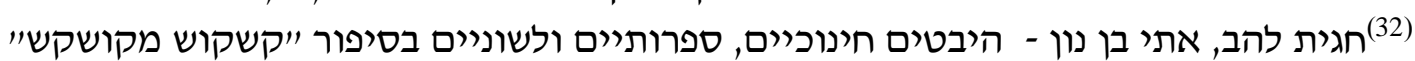

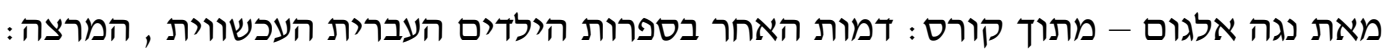

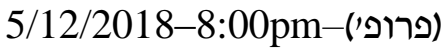



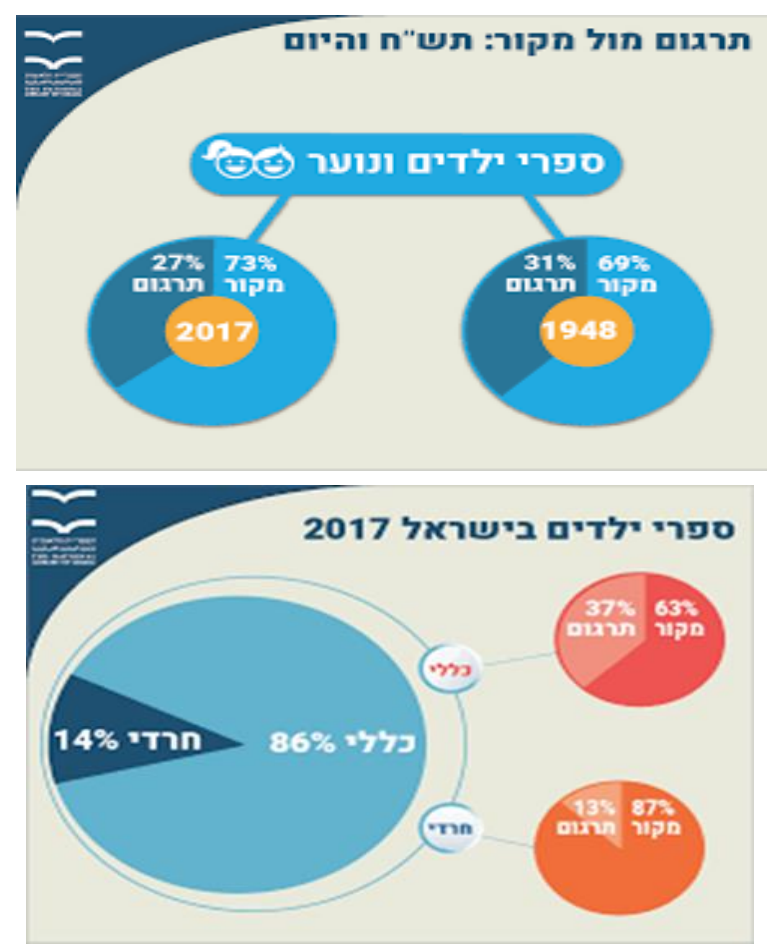

$$
\text { وهذا بعكس أمرين: }
$$

1- تزايد عدد كتب الطفل الصادرة بالعبرية من 69\% إلى 73\% .

2- تقلص عدد كتب الطفل المترجمة من اللغات الأخرى إلى العبرية من 31\% إلى

$$
{ }^{(33)} \% 27
$$

الأمر الذي يعكس توجه إسرائيل الاستراتيجي نحو إحياء العبرية والحفاظ عليها؛ لتنشئة طفل شغوف بالقراءة بالعبرية دون غيرها من اللغات؛ لغرس الأفكار التي يربدونها في عقول الطفل سواء تجاه العربي بصورة عامة أو الفلسطينيين بصورة خاصة.

- - מה קראנו השנה ומה השתנה בספר העברי ב-70 שנות המדינה? - הספריה הלאומות -

$$
\text { - 2018/11/258:00 pm }
$$

https://web.nli.org.il/sites/nli/hebrew/library/depositing/statistics/pages/lgd-statistics-2017.aspx 
قصة "ניר נגד סאלים نير ضد سليح":

يركز البحث على قصة "ניר دגד هאלים نير ضد سليم" لأمنون فيرنر أنموذجا للعنف والإرهاب الذي يتبناه أدب الطفل العبري، لذا قبل عرض القصة ودراستها يجب التعريف بكاتبها. أمنون ثيرنر

أديب، تربوي، متخصص في علم الاجتماع، ولد عام 1936م في كيبوتس "لار גב عين جاث"(34)، كان عضوا في حركة "השומר הצעיר الحارس الفتي"(35)، جُند في الناحال(36)وفي سلاح المظلات، وبعد ذلك انضم إلى كيبوتس "دרמיה كارميا" على حدود قطاع غزة، ولا يزال عضوا به حتى اليوم(37)، كتب مئات القصص والقصائد عن الحرب والنزاع الإسرائيلي الفلسطيني، ووجود الكيان الصهيوني في فلسطين، كما تتاول في أعماله الإرهاب واليتم والتكل

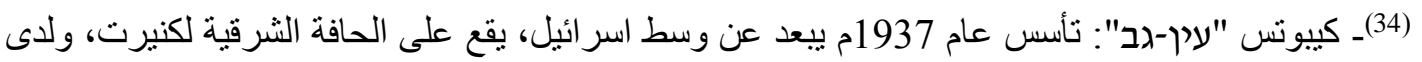

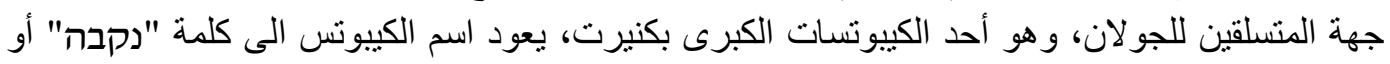

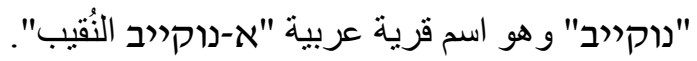

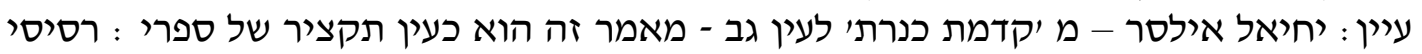

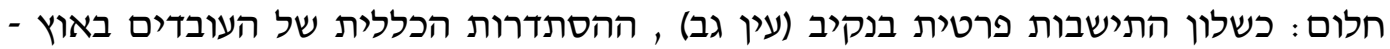
ישראל, תל- אביב 1993 - עמי פרון 146.

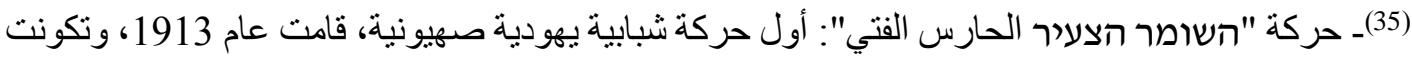

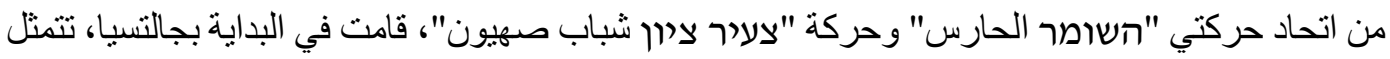

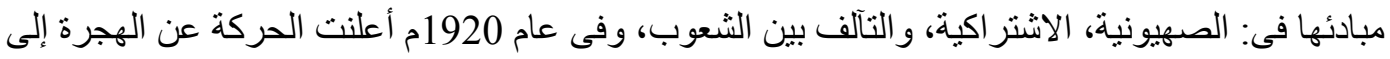

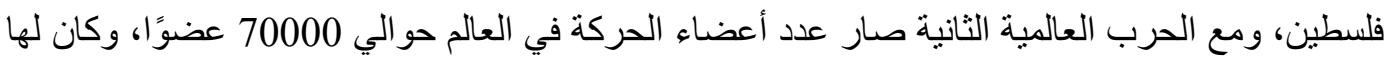

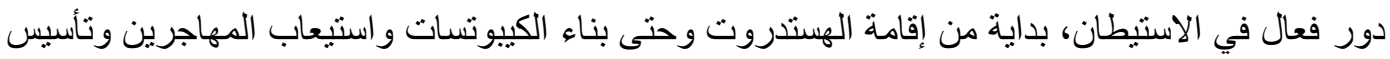
كتائب البالماخ. www.y-m-museum.co.il - עיין: תנועת השומר הצעיר - אתר מוזיאון מרדכי משואה לתקומה -14/11/2016- 11:56 am (36)ـ נח”ל الناحال: اختصار لـ رالاר חלاצי לاחه ويعنى الثباب الطلائعي الدحارب، عبارة عن وحدات

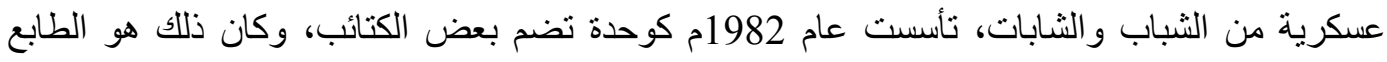

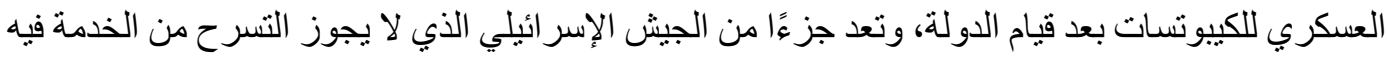

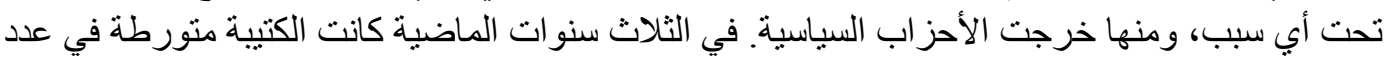

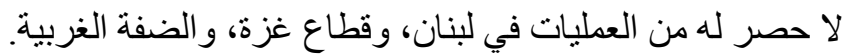

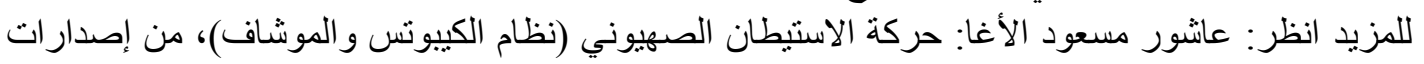

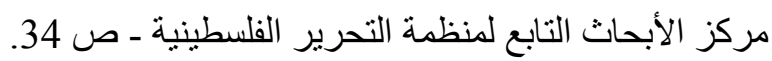
(37)- מדריך פרס רמת-גן לספרות 2013 - עיריית רמת גן - עמיז' 13. 
والبطولة والسلام(38)، وعبر عن موجات العنف والعنصرية التي يمر بها المجتمع الإسرائيلي، تتوعت كتاباته بين القصة والقصة القصيرة والكتب التعليمية، وفي الآونة الأخيرة فاز بالمركز الأول عن مجموعة مقالات "هיפורים אישיים על תל-אביב قصص شخصية عن تل أبيب" البلدة التي قضى بها طفولته، قضى وقتا طويلًا في الوظائف التنظيمية والاقتصادية والتعليمية. حصل على الدكتوراه في علم الاجتماع التعليمي، واستمر في عمله التربوي والتعليمي وألقى سمينارات تعليمية كثيرة، وهو حاليا متطوع للخدمة في الجمعيات التعليمية مثل: "אדه" للتعليم والديموقراطية، وبعض الجمعيات الخاصة بمساعدة الأطفال المتعثرين(39)، فضلا عن ذلك يدير "אתר סיפורי קיבוץ موقع قصص الكيبوتس" الذى يضم أكثر من 1200 قصة، كما أنه عضو في رابطة الأدباء.

من أعماله: "שاמר פעם حارس ذات مرة" (1996م)، المجموعة القصصية "זמן קיבוץ عصر الكيبونس" (2006م)، قصة "ניר נגד סאלים نير ضد سليم" (2012م)، قصة "ניר והמאבק על עץ התות نير والنزاع على شجرة التوت" (2013م)، قصة "ניר של כוכבים ופרחים كواكب وزهور نير" (2014)، المجموعة القصصية "קיבוץ-لادד اשב كيبوتس العامل والعائد" $\cdot^{(40)}\left({ }^{2015)}\right.$

حصل على جائزة "רמת גן رامات جان" للأدب عام 2013م عن قصة "ניר נגד סאלים نير ضد سليم" بهدف تشجيع ودعم الإنتاجات الأدبية العبرية للأطفال والكبار (41). (38)- ניר לוין - ניר נגד סאלים, ספרות ילדים, ביקורת לפי ספר א״ב - 2018/12/21 - 11:00 am http://www.dafdaf.co.il/details.asp?MenuID=1\&SubMenuID=131\&PageID=3557 $\& \mathrm{Ot}=\% \mathrm{~F} 0$

(39)- אמנון ורנר - האם אפשר לשרש את הגזענות כבר בגיל הנעורים? www.ktav.co.il/book.asp?bookID=691 - 21/12/2018 - 1:00 pm. www.simania.co.il/authorDetails.ph?itemld=205951 - אמנון ורנר - אתר סימניה - 22/12/2018 - 10:15pm-

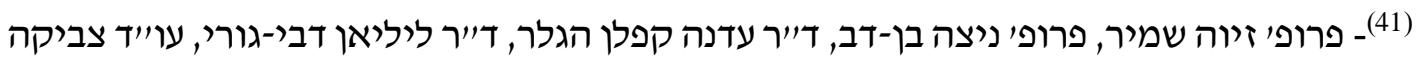
ניר - פרס רמת-גן לספרות 2013- הוצאת עיריית רמת-גן - עמ' 13. 


\section{قصة "ניר נגד סאלים نير ضد سليم":}

صدرت قصة "ניר נגד סאלים نير ضد سليم" عام 2012م عن دار نشر "ספרית פالاלים سفريات بوعاليم"، تدور أحداثها حول الحرب والثجاعة، والثكل الناتج عن الصراع والنزاع الإسرائيلي الفلسطيني، والعداء الثخصي بين الطفل الفلسطيني والإسرائيلي في المدارس الإسرائيلية، كما ثُلقي الضوء على العلاقات العربية الإسرائيلية في فلسطين ولاسيما بين الثباب والصغار ، وعلى الرغم من عرض الأديب لفكرة الإرهاب في قصته، إلا إنه يعبر عن فكرة التعايش السلمي بين الثعبين من خلا الطفلين نير وسليم كما ورد في القصة. عبر أمنون من خلال القصة بجرأة وقوة- عن أمور يفكر كثيرٌ من الإسرائيليين فيها إلا إنهم لا يستطيعون التعبير عنها؛ كالتعايش السلمي وقبول الآخر، على الرغم مما تضمنته القصة من إرهاب، ومحاولة بث روح العنصرية في نفوس النشء الإسرائيلي. اختار الأديب صورة لطفلين يتصارعان غلافًا للقصة رمزا للشعبين الفلسطيني والإسرائيلي؛ ذلك لأن الصور تمثل أهمية كبيرة في أدب الطفل بصفة خاصة، فهي تشير إلى محتوى العمل، كما أن هنالك علاقة بين الصورة واللغة المكتوبة تساعد على التحليل الداخلي للنص. غلاف القصة من تصميم الفنان "נرا זינגר نون زنجر" (42) اختار فيه ألوانًا متتوعة ببراعة لها دلالة معينة؛ (فالخلفية صفراء، حيث يبعث اللون الأصفر على التحذير والتتبيه، واسم الطفلين باللون الأسود الذي يستخدم في بعض الأحيان رمزا للتهديد أو الثر، أما كلمة "رגד ضد" فهى باللون الأحمر الذي بعني استخدام القوة والحرب) إثـارة إلى الواقع المزدوج المَعيش في فلسطين، ويناسب هذا العمل الطفل ضمن الفئة العُمرية من 6- 12 سنة.

- https://www.kibutz-poalim.co.il/nir_salim - אמנון ורנר - ניר נגד סאלים . am 11:00-2018\12\21 עיין גם : מדריך פרס רמת-גן לספרות 2013 - עיריית רמת גן - עמ' 13. 
مظاهر العنف والإرهاب في قصة "ניר נגד סאלים نير ضد سليم":

أضاف الأديب إلى القصة خبراته المتتوعة في المجال التربوي والتاريخ وعلم النفس،

جعلته بعبر في القصة عن رغبته في تغيير وجهة النظر تجاه الآخر، وخاصة لدى الصغار، فالقصة كتبها لابنه نبر الذي قُتل وقت خدمته وهو في الواحدة والعشرين من عمره؛ لذا آثر أن تحمل القصة في العنوان ابنه (نير)، وأضاف أيضا اسم (سليم) مع بيان الضد بينهما (دגד ضد)، وهذا يعنى بداية العداوة من نير الإسرائيلي إلى سليم الفلسطيني وليس العكس، فماذا يريد الأديب أن يؤكد عليه من خلال عنوان القصة؟؟. تحكي القصة عن "نير" الطفل الإسرائيلي في الصف الخامس الابتدائي، قُنل أبوه في إحدى العمليات الإرهابية (وفقا لوصف الأديب) التي استهدفت تفجير مستشفى بتل أبيب، فاتخذ من فَقْد أبيه قدرة على التحدي ظهرت عندما قابل الطفلَ سليم الفلسطيني الذي التحق بمدرسته ودخل الفصلَ ذاتَه الذي ينتمي إليه نير ـ أيضا سليم تأثر بفقدان أخيه الذي قُتل برصاص قوات الاحتلال، ثم نُفيت أسرته إلى الحي الذي يقطن فيه "نير"، ومن ثََّّ اضطر سليم إلى الالتحاق بالمدرسة نفسها التي بها نير، حيث واجه تحديًا كبيرًا؛ لكونه عربيَّا فلسطينيَّا في مدرسة إسرائيلية، جاء في القصة:

"שהסיבה למעבר משפחתו למדינת ישראל הוא סירובה הנחרץ של המשפחה להיות"

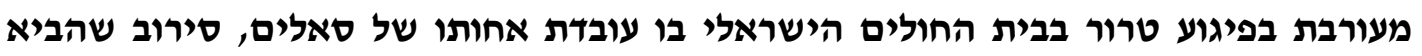

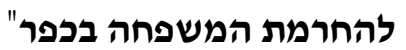

"حيث إن سبب انتقال أسرته إلى إسرائيل هو رفض الأسرة الثديد لأن تكون متورطة في الحادث الإرهابي الذي وقع في المستشفى الإسرائيلي التي تعمل بها أخت سليم، أدى هذا الرفض إلى حجز الأسرة في قرية" حاول الأديب من خلال التحاق سليم بمدرسة إسرائيلية مع نير الإسرائيلي تصوير حالة التناقض داخل المجتمع الإسرائيلي، فقد ساوى بين طرفين مختلفين تماما في الفكر والثقافة والقومية والدين، الأول (سليم) صاحب الأرض والثاني (نير) المغتصِب، ومع هذا فإنه يصور 
الغاصب المتمثل في شخصية الطفل نير بأنه صاحب الأرض، ودليل ذلك أن وجوده بالمدرسة يسبق وجودَ سليم يمثل شيئا مختلفا، وهذا ما ورد في القصة: "לכיתתו של ניר בן ה-11 מצטרף נער ערבי-פלשתינאי בשם סאלים. ניר אינו מוכן להשלים עם כך. בכעסו הוא סוחף אחריו את רוב ילדי הכיתה. אולם דווקא רז, חברו הטוב ביותר, ונטלי,

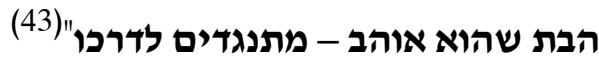

"انضم إلى فصل نير البالغ من العمر 11 عاما صبي عربي فلسطيني اسمه سليم، لكن نير لم يكن مستعدا لتقبُل ذلك، وبسبب غضبه أثنار غالبية الطلبة بالفصل، وربما تحديدًا: راز صديقه المفضل كثيرا، ونتالى صديقته المحبية، فهما اللذان كانا ضده". وعلى الرغم من ذلك إلا أنه من الممكن ألا يعتد البعض بأحداث هذه القصة، ويرى أنها قصة خيالية لكن جذورها واقعية؛ فالخيال هنا يكمن في تتفيذ التعايش المزدوج على أرض الواقع، ويؤكد ذلك الواقع الصعب التتفيذ ما ذكره الأديب في القصة وتباين ردود أفعال التلاميذ في الفصل عند دخول سليم، قال أمنون:

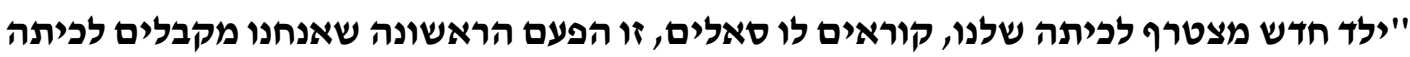

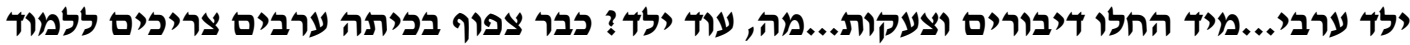

בכפר איפה שהם גרים"(44)

"طفل جديد ينضم إلى فصلنا، يدعونه سليم، هذه المرة الأولى التي نستقبل فيها بفصلنا طفلًا عربيَّا...على الفور بدأت الحوارات والصيحات...ما هذا، طفل آخر؟ الفصل بالفعل مزدحم" فعندما سمع الطفل نير عن انضمام سليم إليهم، شعروا بالاشمئزاز؛ لكونه عربيًّا، ولم يفهوا سبب مجيء طفل فلسطيني لفصل بمدرسة إسرائيلية. وفي وصف رد فعل نير فور رؤية سليم للمرة الأولى عندما قدم إلى الفصل يقول أمنون قثيرنر على لسان نير : n

$$
\begin{aligned}
& \text { (43)- אמנון ורנר - ניר נגד סאלים - רמת גן - ישראל - } 2013 \text { - עמ' } 35 .
\end{aligned}
$$

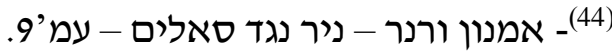


"מעניין מאין הוא השיג את הכובע המגניב הזה"(45)

"بههني معرفة من أين جلب هذه القبعة المسروقة؟"

يشير نير هنا إلى أن سليم لص. وبرى البعض أن العرب يتميزون برائحة معينة، كنوع من العنصرية التي ينشأ عليها الطفل اليهودي؛ فتقول "נاעה نوعا": "שכל הערבים יש להם מין ריח כזה..."(46)" "كل العرب لديهم هذا النوع من الرائحة"

كثف التلامبذ في الفصل شخصيتهم النمطية المُقولبة في موققه تجاه الآخر الفلسطيني الذي بعيش معهم في القربة وليس المدينة فيما عبر عنه الأديب قائلا: "הערבים הם האויבים שלנו ומה פתאום שהם ילמדו איתנו? הם מסוכנים...אף אחד לא יסכים לשבת על ידו"(47) "العرب هم أعداؤنا، وماذا حدث فجأة حتى يدرسوا معنا؟ إنهم خطرون...لن يوافق أي أحد على الجلوس إلى جواره" ويعبر هذا السلوك عن محاكاة الطفل لما يراه من أفعال الكبار ، فالطفل سواء كان إسرائيليا أم فلسطينيا يتعرض إلى مشاهدة الحروب، والعمليات الإرهابية، والهجمات الصاروخية، والعنف بمختلف الأنواع، مدا يجعله بتصرف بعدوانية بصورة لا واعية تجاه كل ما هو عربي أو فلسطيني. فضلا عن بعض الخبايا الأخرى التي أظهرت موقف آباء الأطفال الإسرائيليين من الطفل سليم، مثل ما قاله والد "רוך رون":

"סאלים יכול להביא מחלות מדבקות"(48)

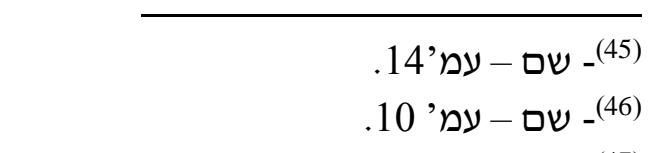

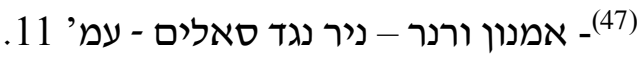

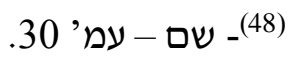


"سليم يمكن أن يكون طفلًا ناقلًا للعدوى"

حتى إن معلم الرياضيات يؤيد فصل سليم الفلسطيني عن الفصل الدراسي، وبستتكر ضرورة وجوده مع الأطفال اليهود في فصل واحد.

يبدو العنف المعنوي والمادي جليا بداية من عنوان القصة، وكذا من خلا الأحداث والإسقاط الذى قدمه الأديب، حيث رمز للعدوان والعنف بين اليهود والفلسطينيين بالطفلين نير وسليم ، بدأت الحبكة بمقاطعة تامة قادها نير الإسرائيلي ضد سليم الفلسطيني؛ انتقاما لوفاة أبيه، حتى إن الأديب جعل جزءا بالقصة يحمل عنوان: "החרه المقاطعة"، وبالتدريج قلَّت هذه المقاطعة على مدار الأحداث، فقد ورد في القصة:

"עלה לי בראש רעיון גאוני: אני אארגן את כל הכיתה שלא ידברו איתו, שלא ישתפו

אותו במשחקים, שלא יהיו חברים שלו, נטיל עליו חרם ונראה מה דגנית המנהלת תעשה"(49) "خطرت ببالى فكرة عبقرية: سوف أنظم كل من في الفصل بحيث لا يتحدثون معه، ولا يشاركونه ألعابا، ولا يكونون أصدقاءه، بحيث نفرض عليه مقاطعة ونرى ماذا ستفعل دجانيت "المديرة؟!" - n استمر نير في التفكير بكيفية المقاطعة فقال: "שלחתי פתקים לכמה ילדים, לרון הגדול הילד הכי חזק שאבא שלו הוא איש חשוב" בממשלה...רועי שלח לי פתק: הוא עוד יכול להכניס פצצה לכיתה"(50) "أرسلتُ رسائل ورقية لبعض أصدقائي منل: رون القوي الذي يعمل والده بوظيفة مهمة في الحكومة..أرسل إليَّ روعي قائلا: إنه (سليم) بستطيع إحضار قنبلة إلى الفصل" يريد من وراء ذلك إظهار سليم في صورة الفلسطيني الإرهابي، وهذا إنما يعكس الفكر الذي ينشأ عليه الأطفال الإسرائيليون.

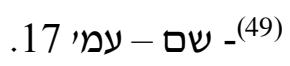

(50) - אמנון ורנר - ניר נגד סאלים - עמי 19. 
وفيما يخص النظام التعليمي المتبع في المدارس الإسرائيلية على هامش ما ورد في القصة نجد أن المعلمة قد خصصت لحالة المقاطعة بين نير وسليم دروسًا كثيرة، وناقثت مع تلاميذها تداعيات تلك المقاطعة، حتى إنها دعت "خديجة" أخت سليم إلى الحضور للفصل؛ لتتحدث عن أسرتها، وجاء رد فعل المعلمة "دلاל ياعل" في رفضها للموقف العدواني تجاه سليم عندما دخل الفصل، وهذا ما ورد بالقصة: "אני מצטערת על מה שניר אמר...אך כאן בכיתה אני מבקשת לוותר על נבואות. ובכלל, ראוי שכולנו נדע שבכל עם יש אנשים טובים ואנשים רעים, ואני בטוחה שמישהו בכיתה יהיה מוכן

לשבת על יד סאלים"(51) (נדים "يالأسفي على ما قاله نير!...لكن هنا بالفصل أطالبكم بالتتازل عن النبوءات. وبصورة عامة من الجدير أن نعلم جميعا أن بكل شعب يوجد الطييون والأشرار، وأنا واثقة من أن شخصًا بالفصل سيكون على استعداد للجلوس جانب سليم" وبعد حديث المعلمة ظهر أحد التلاميذ قائلا:

"רז הוא השפיל את העיניים לרגע ולאחר רגע נוסף אמר: טוב, אני מוכן לשבת על יד סאלים"(52) "نظر لاز للأسفل قليلا وبعد لحظة قال: حسنا، أنا مستعد للجلوس جانب سليم" انطلاقا من طرح الأديب للإرهاب الإسرائيلي القلسطيني من منظور أدب الطقل العبري، فقد عبر عن هذا من خلال الإرهاب المعنوي الذي تجلى في سلوك نير عندما أنار الموجودين في الفصل ضد سليم، وهو نموذج مصغر للشعبين الفلسطيني والإسرائيلي في النزاع على الأرض، وكما ذُكر أعلاه أن نَفْي أسرة سليم إلى قرية والتحاقه بمدرسة إسرائيلية كان عاملا رئيسا في ازدياد العداء والعنف؛ لأنه كلما كانت أطراف الصراع أكثر اندماجًا كان الصراع بينهما أكثر عنفا. 
يؤيد ذلك ما قاله الفيلسوف اليهودي "مارتن بوبر" عن إيمانه وإيمان اليهود بالإرهاب قائلا: "إن جميع الشعب اليهودي فضنّل أن يتعلم الإرهاب من هنلر ... ؛ وذلك لأن هتلر أثنبت أن التاريخ ليس من نصيب من يمنلاك الإيمان، ولكن من نصيب من يمتلك القوة...وإذا امتلك شعبٌ القوةَ فإنها يستطيع أن يَتنل دون حياء"(53). يعبر أمنون عن ذللك في القصة قائلا:

"הכיתה נחלקת למחנות, האווירה מתלהטת ונדמה שאין מוצא מסיר הלחץ הזה. מהו המקור

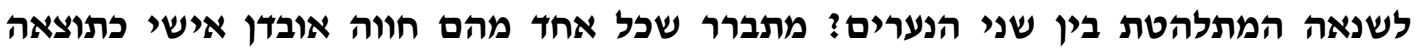
מהסכסוך בין העמים: ניר איבד את אביו בפעילות מבצעית בעזה וסאלים איבד את אחיו הצעיר

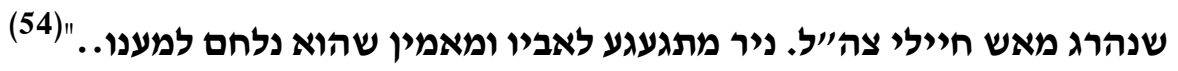
"انقسم الفصل إلى معسكرات، وكانت الأجواء مثارة، وعلى ما يبدو أنه لا خلاص من هذا التوتر ، فما أصل هذا الكره المتفاقم بين الغلامين؟ يتضح أن كلَّا منهما عاش تجربة فَقْدِ؛ نتيجة للصراع بين الثعبين، فَفَقَ نير أباه في عملية تم تتفيذها بغزة، بينما فقدَ سليم أخاه الصغير الذي قُتل بنيران جندي من جيش الاحتلال الإسرائيلي، فيشتاق نير لأبيه ويثق بأنه يحارب لأجله..." يرى بعض النقاد اليهود أن قتلَ العربي يُعد عن طريق الخطأ في حين أن قتلَ الإسرائيلي هو إرهاب، كما بدا العنف هنا معنويا في سلوك فردي منّلّه (نير) ضد (سليم) ممثلا للشعب الفلسطيني، تجسد العنف هنا في المقاطعة انتقاما من الآخر المتمثل في شخصية (سليم). ومن الملاحظ أن الأديب جعل سليم هو الذي حضر جديدا في الفصل، وكأن الأديب يريد أن يؤصل فكرة قِدم وجود اليهود في فلسطين من خلال الطفل نير ، على العكس من عنوان القصة التي تشير أن نير ضد سليم، وهذا يعني أن نير هو الرافض لسليم، مما يدل على العداوة من نير

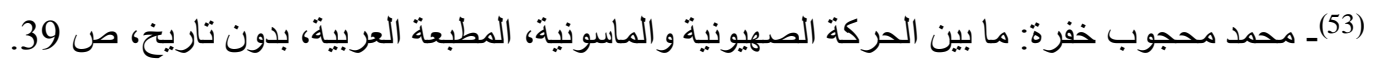

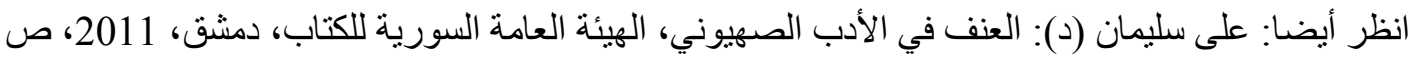
.217.218 11:00am - 2018/12/21 - ניר לוין - ניר נגד סאלים, ספרות ילדים, ביקורת לפי ספר א״-354 http://www.dafdaf.co.il/details.asp?MenuID=1\&SubMenuID=131\&PageID=3557 $\& \mathrm{Ot}=\% \mathrm{~F} 0$ 
الإسرائيلي إلى سليم الفلسطيني وليس العكس، فماذا يريد الأديب أن يؤكد عليه؟ هل يريد أن يجعل الطفلين متقابلين ومتساويين في إثبات حقهما على اعتبار أن كلَّا منهما يمثل شعبه؟ أو أنه يترتب عليه إمكانية العيش معا؟

أدى نزاع الطفلين معا والعنف الذى مارساه ضد بعضهما إلى انقطاع علاقتهما، ثم تدخلت الأسرة لفض هذا النزاع، وإيجاد طريقة مناسبة لكى يتقبل كل منهما الآخر؛ لأن لكل منهما قضيته الخاصة، ومن خلا القصة يحاول الأديب طرح إمكانية قبول كل من الطفلين للآخر ، والتعامل معا في فصل واحد، وهو إسقاط على حال الشعبين الفلسطيني صاحب الأرض والصهيوني المغتصِب، وهذا يتفق مع هدف البحث الذى يبرز كيفية طرح الفكر الإرهابي الإسرائيلي في أدب الطفل العبري، وعبر أمنون قيرنر عن ذلك التوجه الجديد المسمى: "הاמניזه الإنسانية" الذي يعد مرادفًا لمصطلح "דا קיוه" التعايش المزدوج"؛ نتيجة شعوره بالازدراء تجاه موجة العنف والإرهاب والعنصرية التي يعيشها المجتمع الإسرائيلي كما يرى الأديب، فيقول: "ניר לומד שהמציאות אינה חד ממדית ושאפשר להביט בה באופנים שונים. אט-אט מחלחלים לנפשו דבריה של אמו: " שנינו איבדנו איש יקר ולשנינו עצוב נורא, אך כדי שנמשיך

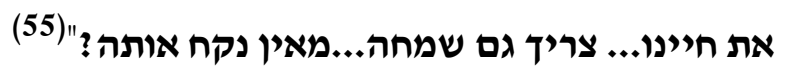
"تعلم نير أن الواقع ليس أحاديا لهذه الدرجة، وأنه من الممكن أن ننظر إليه برؤى مختلفة. روبدا روبدا تبادر إلى ذهنه أقوال أمه: "كلانا فقد شخصًا عزيزًا، وكلانا يشعر بالأسى البالغ، ولكن لكي نستمر في حياتتا لا بُدّ أيضا من وجود السعادة...فمن أين نكتسبها؟" وعلى الرغم من تأكيد الأديب على الإرهاب الإسرائيلي ضد الفلسطينيين في القصة، إلا إنه يرى فُتُورَ صوت الحوار في أدب الطفل العبري حول النزاع على الأراضي الفلسطينية، ويرى أن هذه القصة (موضوع البحث) تعبر عن توجه نحو لفت ثُراء أدب الطفل الصغار على ما يتم دفعه لهم وراء الجدران الآخذة في البناء، ألا وهي: قضية التعايش المزدوج! ، هنآك العديد ممن يؤكدون على مضمون التفاؤلية والأمل في الأدب، وهناك من يرى عكس ذلك، أمثال: "ריבלין

(55) 
ريفلين" الذى عبر عن رأيه في العرب قائلا: "شُعُرت باليأس من العرب"(56)، حيث إن وجود هذا التوجه السائد في إسرائيل جعل بعض أماكن بيع الكتب تُقلص حجم مبيعاتها لقصة "نير ضد سليم"(57).

مما سبق نستتج أن هذا التتاظر بين تجربة الطفلين تم التعبير عنها بضمير المتكلم عن طريق شخصية نير التي حظيت بوصف كامل لتجربته وتحدياته وحياته، وفي المقابل شخصية سليم تم عرضها من خلال المقاطعة قولا وفعلا التي فرضها نير عليه، ومن ثنَّ على مدار الأحداث لا يحاول نير الاقتراب منه، أو التعامل معه بصورة مباشرة، وهذا بحد ذاته بلقي الضوء على المجتمع الإسرائيلي فيما يخص علاقته بالفلسطينيين في إطار إنساني وليس عسكريًّا، ويُعد جانبًا من الإرهاب المعنوي الذي يقود إلى الإرهاب المادي على مستوى سياسة إسرائيل (58). ومن هنا نخلص إلى أنه: إذا كان هذا هو النمط الذي ينشأ ويتربى عليه الأطفال الإسرائيليون فمن البََهِيّ أن نجد أجيالا تؤمن بمفاهيم العنصرية والكراهية تجاه الآخر العربي الفلسطيني. مما سبق يتضح أن القصة تعرض وضعًا فكريَّا يُمنل الطفلان فيها جزعًا من الواقع، وحاول أمنون عرض ذلك بصورة مثالية، فقد تعاون في إصلاح هذا التشوه الفكري بعض المدرسين في المدرسة والوالدان في المنزل، فقد اعتاد على معالجة ذذلك في الكيبوتسات منذ سنوات حيث لأمنون شخصية مثالية إيجابية ـ ومن اللافت للنظر عرض أمنون لمدرسة تقوم بعمل أسبوع للايموقراطية وكذا تضم تلاميذ من أصل مختلف. وفي قصته يحاول أمنون الخروج من العنصرية إلى التعايش وخاصة بين الأطفال، فقد عبر عن العنصرية المتطرفة بين التلاميذ

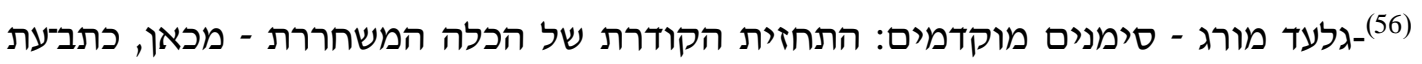

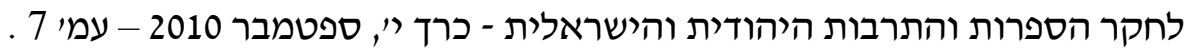

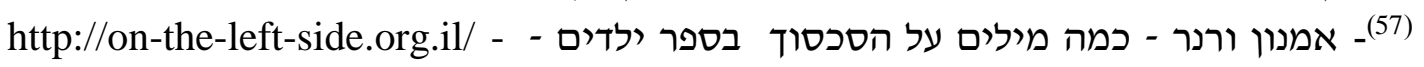
22/12/2018-8:00 pm (58)- דרי שי רודין - דמות הערבי בספרות הישראלית לילדים ולנוער: 1985-2015 - עמ’ 49,50. https://www.dyellin.ac.il/sites/default/files/journals/childrens_literature/aug2015/august2015_dmu thaarvi.pdf 
غير أن القصة خلت من أية ألفاظ خارجة عن الإطار، فضلا عن ذلك طرح أمنون العربيَّ بصورة إيجابية لدرجة كبيرة من حيث المظهر والجوهر وأيضا متحدثا بالعبرية أي مضاهيا لنظيره الإسرائيلي، حيث ذكر الأديب في وصفه لسليم: "הוא היה גבוה, היה לו עיניים שחורות, והשיער שלו היה מגולח כמעט לגמרי מאחור

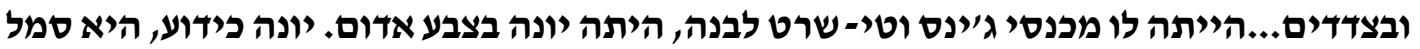
השלום, הוא בטח רוצה להתחנן אלינו, חשבתי"(59) "كان فارع الطول، ولديه عينان سوداوان، وحليق الشعر على الأقل من الخلف والجوانب، وكان مرتديا بنطال جينز وتيشيرت أبيض عليه حمامة بيضاء باللون الأحمر ، فالحمامة كما هو معروف رمز للسلام، اعتقدت أنه بالفعل يريد التودد إلينا" من الملاحظ هنا أنه رغم إسقاط الأديب على التوجه الجديد "הומניזه"، إلا أنه جعل مبادرة السلام تبدأ من سليم الذي يرمز للشعب العربي الفلسطيني، ولكن من المعروف أن تكون حمامة السلام بيضاء، فلماذا جعلها حمراء؟ هل دلالة من الأديب على ما وصلت إليه الأوضاع الحالية بين الثعبين أو أن الأمر صدفة؟! عبرت القصة أيضا عن التنوع الأيديولوجي في المجتمع الإسرائيلي بفلسطين، منل: موقف والدة نير الذي كان واضحا في رفضها للعنف الذي يمارسه ابنها ضد سليم، وأنه لا ينبغي الانتقام الآن (وتعقيبا على ذللك أنها لم تلغ الانتقام من فكرها، بل إنها قامت بتأجيله فقط، مما يدل على الفكر العنصري الأصيل في تفكير الأسر الإسرائيلية فيما تبثه للنشء)، فقد ورد في القصة حوار نير مع والدته:

"אתה הרי יודע שבינינו לבין הערבים יש מצב של מלחמה כבר הרבה מאוד שנים. לפעמים

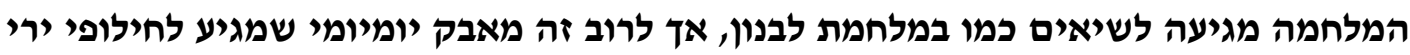

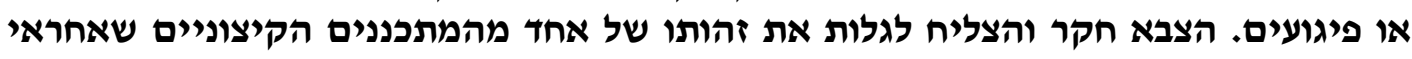

למותם של רבים. אבא שבאותם ימים שירת במילואים...ובקרב גם אבא נהרג" (60)

(59)

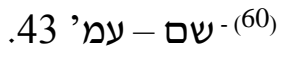


"إنك حقا تعلم أن بينتا وبين العرب حالة من الحرب الممتدة منذ سنوات، وفي بعض الأحيان تصل الحرب لقمتها كما في حرب لبنان، ولكن غالبا تكون أزمة يومية تصل لتبادل إطلاق النيران أو إصابات، وقد بحث الجيش ونجح في الكثف عن هوية أحد المنآمرين المتطرفين المسئول عن موت كثيرين، وكان أبوك حينئذ في خدمته العسكرية...وفي الحرب قُتل أبوك أيضنا"

يتضح مما سبق رغم محاولة الأم إقناع نير بقبول سليم، إلا إنها حاولت إظهار الجيش الإسرائيلي بأنه دائما على أهبة استعداد يكثف المتآمرين فضلا عن أنها وصفتهم بالمتطرفين، وأنهم هم الذين يقتلون الأبرياء، وبالفعل هذا ما ينشأ عليه الطفل الإسرائيلي والذي اتفق مع رد فعل نير تجاه حديث والدته الذي بدا فيما ورد بالقصة: "הדם עולה לי לראש מרוב הכעס עליה , מה היא עוזרת לערבים? היא שכחה מה הם עשו לאבא?"(61) "وصلت لقمة استيائي غضبا منها، كيف تساعد العرب؟ أنسيت ما فعلوه بأبي؟" ومع تطور الأحداث في جزء في القصة وضعه الأديب تحت عنوان: "מי ינצח? من يفوز؟" يثارك فصل نير وسليم في مباراة كرة قدم، حيث فاز فصلهما على طلاب الفصل السادس في مباراة كرة القدم، وذلك بفضل التعاون بين نير وبين نتالى وسليم، ورد في القصة: "בשיעור האחרון התקיים בבית הספר משחק הגמר בכדורגל. אנחנו- כיתה ה', נגד כיתה ו"...(62) "أُقيمت بالمدرسة في الحصة الأخيرة مباراة النهائي لكرة القدم، فصلنا- الصف الخامس، ضد الصف السادس " حيث كانت النهاية جيدة على المستوبين الفردي والجماعي؛ أما على المستوى الجماعي ففاز فريق الفصل، وأما على المستوى الفردي فشعر الطرفان (نير وسليم) بفرحة المكسب التي (62) - אמנון ורנר - ניר נגד סאלים - עמי 45 (62) - (62) - שם - עמוץ 110. 
جعلت الحزن يتحرر جزئيا من داخلهما، ومن خلال ذلك يبدو أن الأديب يرى أن الطفلين أبرياء من التشتئة التي تربيا عليها ولاسيما تتشئة الطفل "نير" الإسرائيلي، وإنما هما ضحية واقع أليم فرضته ظروف الاحتلال وأهدافه الصهيونية؛ حيث إن الإرهاب يمنل استراتيجية سياسية يتبعها الكيان الصهيوني قائمة على التهديد بالعنف والألم كأداة رئيسة لها. وهي الرسالة التي ذكرها أمنون فيرنر في القصة؛ لإيصال رسالة للكبار من وجهة نظر أدب الطفل قائلا: "שכל הילדים משני העמים ימצאו את הדרך לחיות יחד בשלום ليجد كلا الطفلين من الثعبين الطريق للعيش معا بسلام"(63)؛ لذا آثر أن تحمل القصة عنوان ابنها (نير)، وأضاف أيضا اسم (سليم) مع بيان الضد بينهما، وهذا يعني بداية العداوة من نير الإسرائيلي إلى سليم الفلسطيني وليس العكس، فماذا يريد الأديب أن يؤكد عليه من خلال عنوان القصة؟ من النتائج التي تم التوصل إليها بعد دراسة قصة "ניר دגד סאלים نير ضد سليم" لأمنون ثيرنر، يمكن حصر أهداف أدب الطقل الإسرائيلي على هذا النحو: 1- - البحث عن الذات اليهودية وتشجيع الاستيطان. 2- - إثبات أن اليهود هم ضحايا التاريخ، وغرس مفهوم اضطهادهم في النصوص التي تُقدم لهم. 3- مفهوم القومية اليهودية والثعب اليهودي الواحد. 4- كره العربي ولاسيما الفلسطيني، والتأكيد على أنه هو العدو الوحيد لليهود. 5- تزكية الروح الدينية وربطها بالبعد الاستراتيجي للصهيونية. 8- فلسطين أرض بهودية تخص اليهود وحدهم بموجب وعد إلهي. 9- الشعب اليهودي شعب مختار من الله متفوق على من عداه من الشعوب. 10- تؤكد القصة على أن الشعب اليهودي يحافظ على عرقه، ويرفض الاندماج مع الآخرين، وأنه بسعى ليقيم دولتَه -كما حددتها التوراة- من النيل إلى الفرات. 
لذا؛ يتبين لنا أنه يستحيل التعايش السلمي بين المسلمين واليهود؛ بسبب العقيدة التي نشأوا عليها، والاستراتيجية المُتبعة في الاستيطان، وتبني المشروع الصهيوني، وكذلك العداء الأزلي للإسلام والمسلمين، الأمر الذي يتطلب المعرفة الكاملة بالعدو، ودراسة التركيبة الديموجرافية والاجتماعية، والوقوف على ثغراته، فنجد أن المقالاتِ النقديةَ العبريةً التي تحدثت عن القصة استعمَلَتْْ التعبير : النزاع /الصراع الإسرائيلي الفلسطيني، وليس العكس كما هو رائج في بعض المراجع، وهذا يدل على التوجه السائد بأن من بدأ الصراع هم الإسرائيليون وليس الفلسطينيين، ومن جهة أخرى يريدون تحديد الصراع بينهم وبين الفلسطينيين فقط دون غيرهم من العرب؛ لأنهم يخافون اتحاد العرب. 


\section{قائمة المراجع}

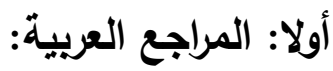

1- أحمد زلط (د)- مؤثرات أيديولوجية في أدب الطفل العبري (مقارنة وتأويل) - عالم الفكر -

$$
\text { العدد الرابع - المجلد } 35 \text { - 2007م. }
$$

2- إسماعيل عبد الفتاح (د) - رانية حسن أبو العينين - معايير قياس جودة كتب الطفل

$$
\text { (محددات/انتقاد/اختيار/نقد/تحليل وتطوير أدب الطفل) - 2001م. }
$$

3- إسماعيل صبرى مقلد (د) - العلاقات السياسية الدولية: دراسة في الأصول والنظريات -

الكويت - جامعة الكويت ، 1982.

4- اللواء د/محمد فتحي عيد: الإرهاب والمخدرات - جامعة نايف العربية للعلوم الدينية - الطبعة

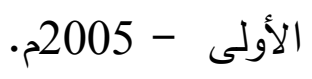

5- رشاد عبد الله الثامى (د) - إثكالية اليهودية فى إسرائيل - عالم المعرفة - 1997/8 6- على سليمان (د) - العنف في الأدب الصهيوني -الهيئة العامة السورية للكتاب - دمثق .2011

7- محمد محجوب خفرة - ما بين الحركة الصهيونية والماسونية - المطبعة العربية - بدون تاربخن.

$$
\text { 8- معين أحمد محمود - يوميات مناحيم بيغن - بيروت - سمبه ام. }
$$

9- ناصر عبداله الغفاري، ناصر عبدالكريم العقل (د)- الموجز في الأديان والمذاهب المعاصرة

$$
\text { - دار الكنوز - السعودية - 2005م. }
$$

10- عاشور مسعود الأغا - حركة الاستيطان الصهيوني (نظام الكيبونس والموشاف) - من إصدارات مركز الأبحاث التابع لمنظمة التحرير الفلسطينية. 
1- مجلة "دراسات مستقبلية"، العدد الثالث - منير محمود بدوى (د) - مفهوم الصراع، دراسة في الأصول النظرية للأسباب والأنواع - مركز دراسات المستقبل - جامعة أسيوط - يوليو 1997

2- مجلة قضايا إسرائيلية - العدد الثالث - أورئيل أوفلك - الحذر ! سم قاتل، سلسلة قصص الفنيان "حسمبا" ليجئال موسينزون - المركز الفلسطيني للدراسات الإسرائيلية - 2001م. 3- مجلة أقلام العراقية - عدد VY - غالب هلسا - الحروب الصليبية - 9 ام.

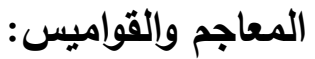

1- سعيد عبد السلام (د) - دراسة معجمية لمصطلحات الأدب، عبري-عربي، مع مسرد للألفاظ العربية - القاهرة- 1997م. ثانيا: المصادر والمراجع العبرية:

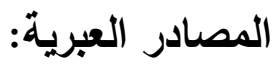
אמנון ורנר - ניר נגד סאלים - רמת גן - ישראל - 2013.

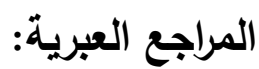

1- א אוראיל אופק - ספרות ילדים העברית 1900: 1948 - כרך שני. 2- - גדי פארן, עמי פדהצוג, אריה פרליגר - התמודדות מול טרור בירושלים 1967-2002 - מכון ירושלים לחקר ישראל - 2005. 3- זהר שביט - מעשה ילדות, מבוא לפואטיקה של ספרות ילדים - האוניברסיטה הפתוחה תל-אביב - 1996.

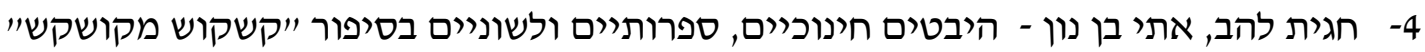

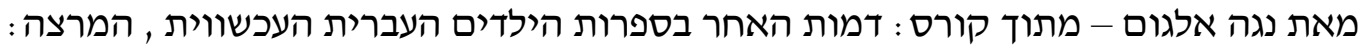
מירי ברוך (פרופי)- 2017. 5- פרי : רסיסי חלום: כשלון התישבות פרטית בנקיב (עין גב), ההסתדרות הכללית של העובדים באוץ - ישראל, תל- אביב 1993. 6- לאה גולדברג - אתר מאגרי מדע פדגוגיים - המכללה האקדמית - בית ברל (ע״ר)- בלי

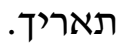
7- מדריך פרס רמת-גן לספרות 2013 - עיריית רמת גן - 2013.

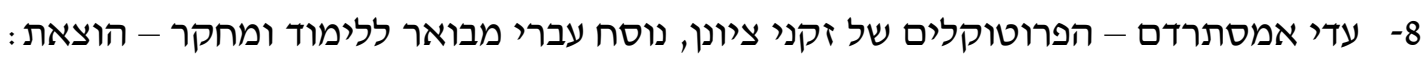
דרורים - מהדורה שנייה ומעודכנת - אפריל 2018. 
9- פרופ' זיוה שמיר, פרופ' ניצה בן-דב, ד״ר עדנה קפלן הגלר, ד״ר ליליאן דבי-גורי, ען"ד צביקה

ניר - פרס רמת-גן לספרות 2013- הוצאת עיריית רמת-גון - 2013.

10- שונית כהן - ספרות למען סובלנות, רשימה של ספרי ילדים ונוער נגד גזענות ולעידוד הומניזם ושלום - מכללת אורנים - בלי תאריך.

11- שי רודין, אביבה רון - "צריך להכניס אותו לעונש": ילדי גן מגדירים אלימות בעקבות שיח ביבל-ותרפי חינוכי על אודות ספרי ילדים - זמן חינוך 4 - 2018.

الدوريات العبرية والمقالات:

1- ספרות ילדים ונוער - חוברת א׳ - אתי רוזנטל (ד״ר)- הערבים הגלומים בספרות הילדים של הגיל הרך -דצמבר 2006.

2- מכאן, כתב־עת לחקר הספרות והתרבות היהודית והישראלית - כרך י, ספטמבר 2006. 3- לאה גולדברג - אתר מאגרי מדע פדגוגיים - המכללה האקדמית - בית ברל (ע״ר)- 2019. 4- דינה ציונית - על פועלה של הסופרת והמשוררת לאה גולדברג - 2019. 5- יעל לקסמן-בהט - ילדות טובות: הבניית יחסים מגדריים בספרות הילדים הישראלית

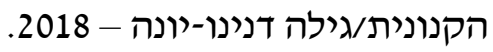

6- דו קיום: כיצד מתוארים היחסים בין יהודים וערבים בספרות הילדים - מאמר באתר: ביקורים: ספרות ילדים אמנותית עם מתוארים אחריות חברתית- 2008.

7- דרי שי רודין - דמות הערבי בספרות הישראלית לילדים ולנוער : 1985-2015- 2015. 8- מה קראנו השנה ומה השתנה בספר העברי ב-70 שנות המדינה? - הספריה הלאומות - 2018.

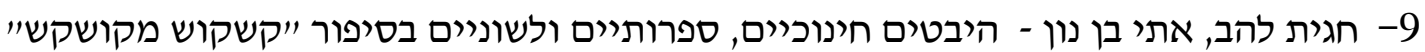
מאת נגה אלגום - מתוך קורס: דמות האחות האר בספרות הילדים העברית העכשווית , המרצה:

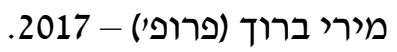

10- ניר לוין - ניר נגד סאלים, ספרות ילדים, ביקורת לפי ספר א״ -

11- אמנון ורנר - האם אפשר לשרש את הגזענות כבר בגיל הנעורים? - 2018.

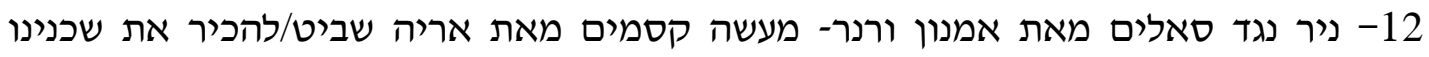

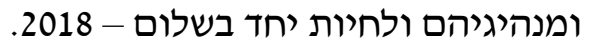

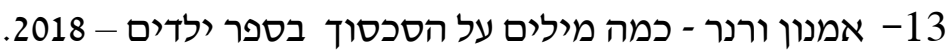
14- ספרות ילדים סטרילית?- סוכן תרבות - 2018.

\section{المعاجم والقواميس العبرية:}

www.morfix.co.i1 המילון האלקטרוני: מורפיקס

2- - המלון החדש - אברהם אבן-שושן - כרך א-ד - הוצאת :קריית ספר - ירושליים - 1983.

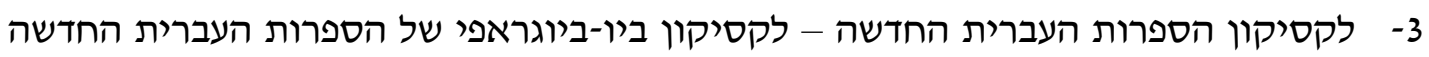
יוסף גלרון גולדשטיין - לקסיקון אלקטרוני (www.liberary.osu.ed).

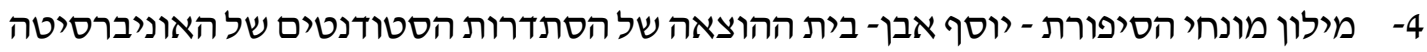

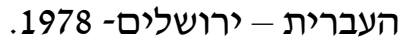




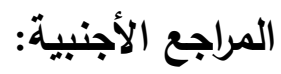

1- Abu Nimr, Op. Cit.

2- Lopez\& Stole, Op. Cit.

مواقع شبكة المعلومات:

'www.library.osu.edu -1

יוסף גלרון גולדשטיין - לקסיקון הספרות העברית החדשה - לקסיקון ביו-ביוגראפי של

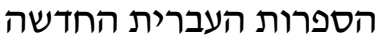

www.simania.co.il -2

www.beta.nli.org/ar/books/ -3

موقع المكتبة الإسرائيلية الوطنية: הספרייה הלאומית.

www.elaph.com -4

www.bikurim.wordpress.com -5

www.dyellin.ac.il/ -6

$\underline{\text { www.gilrach.co.il }}-7$

www.dafdaf.co.il -8

www.ktav.co.il -9

www.kibutz-poalim.co.il -10

http://hitchhikersgui.de/Charles_Perrault -11 